\title{
Alternative Interventions to Prevent Oxidative Damage following Ischemia/Reperfusion
}

\author{
Simón Quetzalcoatl Rodríguez-Lara, ${ }^{1}$ Ernesto German Cardona-Muñoz, ${ }^{1}$ \\ Ernesto Javier Ramírez-Lizardo, ${ }^{1}$ Sylvia Elena Totsuka-Sutto, ${ }^{1}$ Araceli Castillo-Romero, ${ }^{2}$ \\ Teresa Arcelia García-Cobián, ${ }^{1}$ and Leonel García-Benavides ${ }^{1}$ \\ ${ }^{1}$ Instituto de Terapéutica Experimental y Clínica, Departamento de Fisiología, CUCS, Universidad de Guadalajara, \\ Calle Sierra Mojada 950, Colonia Independencia, 44340 Guadalajara, Jal, Mexico \\ ${ }^{2}$ Laboratorio de Neurofisiología, Departamento de Fisiología, CUCS, Universidad de Guadalajara, \\ Calle Sierra Mojada 950, Colonia Independencia, 44340 Guadalajara, Jal, Mexico
}

Correspondence should be addressed to Leonel García-Benavides; drleonelgb@hotmail.com

Received 21 June 2016; Revised 23 September 2016; Accepted 12 October 2016

Academic Editor: Kota V. Ramana

Copyright (C) 2016 Simón Quetzalcoatl Rodríguez-Lara et al. This is an open access article distributed under the Creative Commons Attribution License, which permits unrestricted use, distribution, and reproduction in any medium, provided the original work is properly cited.

Ischemia/reperfusion (I/R) lesions are a phenomenon that occurs in multiple pathological states and results in a series of events that end in irreparable damage that severely affects the recovery and health of patients. The principal therapeutic approaches include preconditioning, postconditioning, and remote ischemic preconditioning, which when used separately do not have a great impact on patient mortality or prognosis. Oxidative stress is known to contribute to the damage caused by I/R; however, there are no pharmacological approaches to limit or prevent this. Here, we explain the relationship between I/R and the oxidative stress process and describe some pharmacological options that may target oxidative stress-states.

\section{Introduction}

As early as 1986, Murry et al. [1-3] observed that, after occlusion of the coronary artery and posterior reperfusion, lesions were present in myocardial tissue in the dog, which seemed to accelerate necrotic damage. In addition, histopathological changes in tissues observed at 30-60 min of reperfusion were similar to that observed at $24 \mathrm{~h}$ of permanent ischemia. Ischemia/reperfusion (I/R) lesions are present in many diseases that affect multiple health systems [4-8]. The effect of these lesions can range from irreversible damage to death of the injured tissue (e.g., cardiovascular, renal, neuronal, and hepatic) [8].

One of the main events that contribute to this damage is the formation of reactive oxidative species (ROS) and reactive nitrogen species (RNS) and subsequent redox signaling disruption in mitochondria [3, 9-11].

The current therapeutic approaches include pharmacological and mechanical interventions. To date, the mechanical approaches (preconditioning, postconditioning, and remote ischemic preconditioning) have proven to be the most promising; however, these methods are invasive, cannot be used for all cases, and the end results can vary. In contrast, the pharmacological interventions currently available are unable to produce any significant effects on patient prognosis [1220]. The establishment of animal models of $I / R$ injury has aided in determining the molecular mechanisms involved and possible pharmacological targets.

\section{What Is I/R Lesion?}

I/R lesions can be defined as a phenomenon that occurs following the block of arterial blood flow to tissue or an organ, which produces a severe imbalance in oxygen and metabolic substrates. This imbalance causes tissue hypoxia and inhibits metabolic processes within cells; paradoxically, the restoration of arterial blood flow and reoxygenation is 


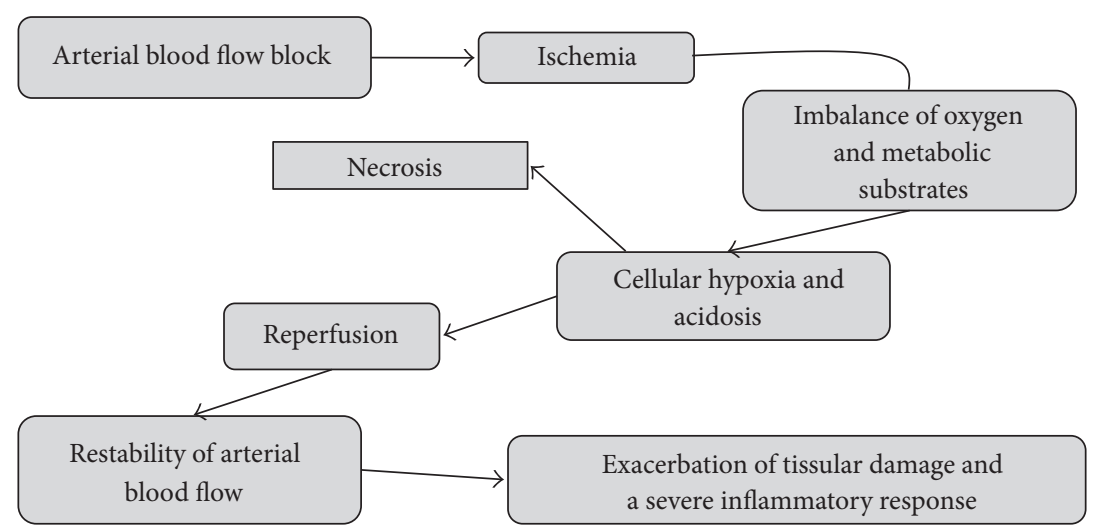

FIGURE 1: Ischemia reperfusion process. Sequence of stapes and clinical states.

associated with the exacerbation of tissue damage and a severe inflammatory response (Figure 1) [3, 12-22].

\section{Mechanism of Lesion}

The formation of lesions is caused by multiple events that are triggered by the block of arterial flow and its restoration. The most critical time point in lesion formation is $72 \mathrm{~h}$ after reperfusion and the limitation in damage is at 7 days after the initial reperfusion, with recovery taking more than 15 to 90 days $[3,10,11,20]$.

There are eight pathophysiological processes that contribute to lesion formation (Figure 2). These processes can act separately and consecutively, and although their order varies depending on the tissue, they all overlap in one crucial step: permanent mitochondrial lesion and redox signaling disruption $[3,10,11,21-25]$.

\section{Imbalance in Metabolic Substrates and Oxygen}

Metabolic substrates such as glucose and oxygen are necessary for mitochondrial ATP production. When oxygen concentration is depleted and aerobic glycolysis stopped, cells switch to anaerobic metabolism, causing an increase in lactic acid production that diminishes cytosolic $\mathrm{pH}$. This acid microenvironment within the cytosol helps cells to survive ischemia. Time is an essential component in reaching this imbalanced state and varies depending on the tissue; for example, cardiac cells can tolerate $20 \mathrm{~min}$ of ischemia before necrosis and hepatocytes and renal cells more than $30 \mathrm{~min}$, while neuronal cells can tolerate no more than $20 \mathrm{~min}$. Some tissues (e.g., skeletal muscle cells) excel compared with others and can tolerate $2 \mathrm{~h}$ of ischemia $[2,3,13,15,53,54,64,65,91-$ 106].

\section{Increase in Cytosolic Cation Levels}

During arterial blood flow occlusion (ischemia), cellular metabolism continues. However, the moment an imbalance in cation levels is detected, a series of changes in the cell occurs, which starts with the activation of the $\mathrm{Na}^{+} / \mathrm{Ca}^{+2}$ exchanger and L-type $\mathrm{Ca}^{+2}$ channels, which cause an increase in the levels of cytoplasmic $\mathrm{Ca}^{+2}$. This increase triggers the activation of $\mathrm{Na}^{+} / \mathrm{H}^{+}$exchangers that consequently results in an increase in $\mathrm{H}^{+}$and changes the $\mathrm{pH}$ of the cell. These events impair the metabolic processes of the cell and affect $\mathrm{K}^{+}$ channels in mitochondria [21, 23, 33, 64, 100, 101, 107-115].

During the reperfusion process, the cell tries to restore the change in $\mathrm{pH}$ by activating the $\mathrm{Na}^{+} / \mathrm{HCO}^{-}$exchanger. The efflux of $\mathrm{H}^{+}$produces an influx of $\mathrm{Na}^{+}$increasing the concentration of $\mathrm{Na}^{+}$in the cytosol. This increase activates the $\mathrm{Na}^{+} / \mathrm{Ca}^{+2}$ exchanger, which leads to an increase in cytosolic $\mathrm{Ca}^{+2}[21,23,33,64,100,101,107-115]$. The high concentration of $\mathrm{Ca}^{+2}$ in the cytosol activates several proteases and other proteins that lead to dysfunction and destruction of organelle membranes and corruption of normal metabolism $[21,23,33$, 64, 100, 101, 107-115].

In myocardial cells, changes in membrane potential traffic activity and water migration secondary to voltage-dependent channel aperture lead to arrhythmia and myocardial stunning. In the kidney, glomerular charge is inverted and overloads filtration solutes, increasing water, protein, and electrolyte loss through urine production. In hepatocytes, membrane potential and $\mathrm{pH}$ changes are detected, which suppress and activate many enzymes that optimally operate at a neutral $\mathrm{pH}$, and lead to edema and necrosis $[21,23,33$, $64,100,101,107-115]$.

\section{Mitochondrial Lesions}

The metabolic changes in the cytosol following ischemia affect the normal function of mitochondria, which produces an adaptive response brought about by increasing levels of cytosolic $\mathrm{Ca}^{+2}$ and decreases in oxygen, NADH, pyruvate, $\mathrm{ADP}$, and $\mathrm{Pi}$. The high concentration of $\mathrm{Ca}^{+2}$ activates mitochondrial calcium-sensitive $\mathrm{K}^{+}$channels (mtKca) and mitochondrial nitric oxide synthase (mtNOS), which increases the levels of nitric oxide (NO ${ }^{\bullet}$ ) (Figure 3) [21, 23, $33,64,100,101,107-115]$. $\mathrm{NO}^{\bullet}$ blocks complex IV in the respiratory chain, inducing an influx of electrons into the mitochondrial matrix and depletion of ATP. NO ${ }^{\bullet}$ reduces molecules to superoxide anions $\left(\mathrm{O}_{2}{ }^{-}\right)$and produces high 


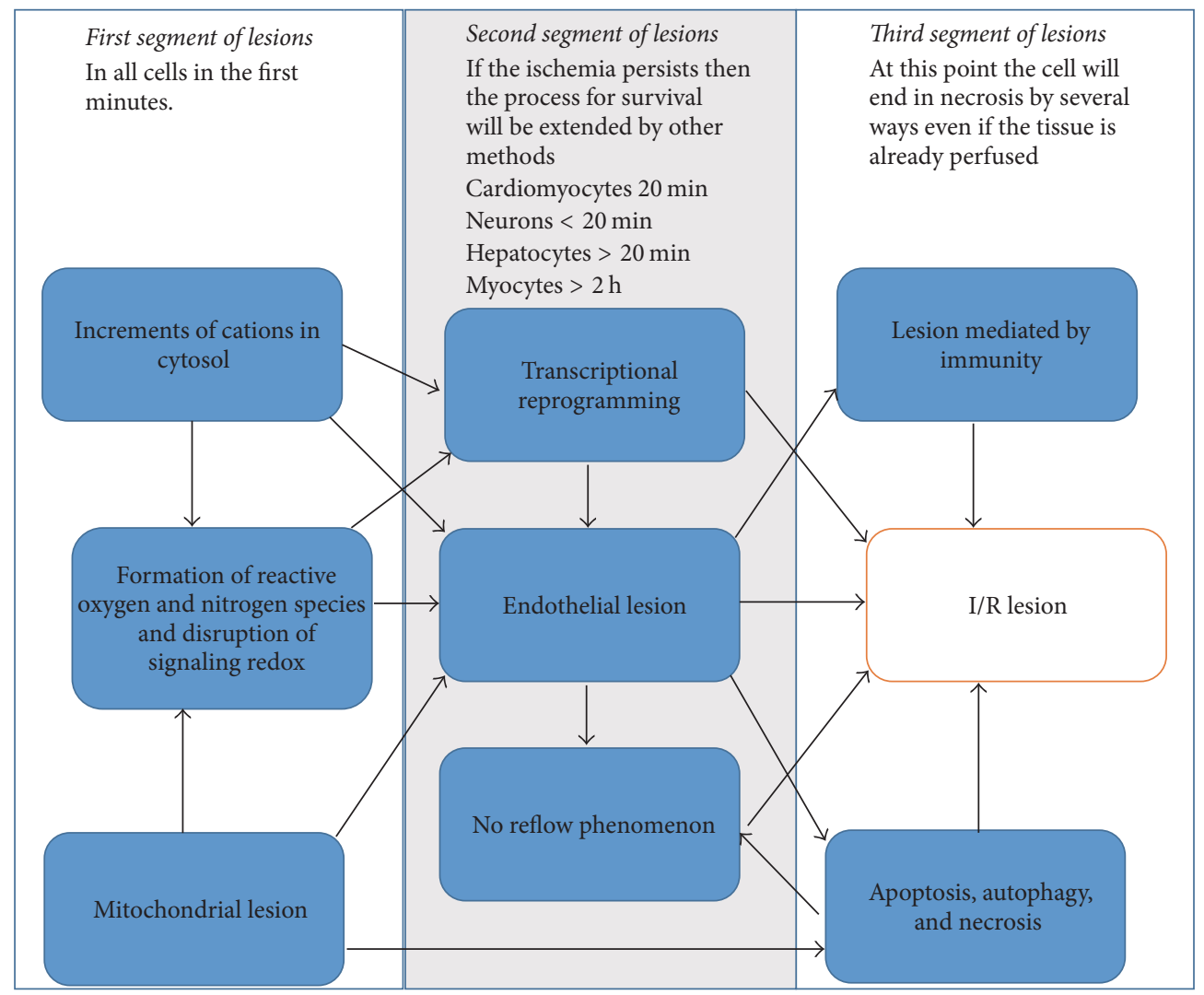

FIGURE 2: Chronology and correlation of I/R lesion "hot-points." The ischemic process is distinct in each tissue but can be divided into three segments that are shared among all cell types yet show differences in specific details (e.g., timing). The time to damage is prior point.

levels of peroxynitrite $\left(\mathrm{ONOO}^{-}\right)$. The loss of ATP is caused by the impairment to ATP recycling, depletion of substrates, and inhibition of complex IV in the respiratory chain [21, $23,33,64,100,101,107-116]$. This influx of electrons into the mitochondrial matrix and the efflux of protons to the cytosol maintains mitochondrial membrane potential; however, it results in an increase in the production of ROS, RNS, and edema and makes the mitochondrial matrix an alkaline environment [21, 23, 33, 64, 100, 101, 107-116].

The ATP depletion induces the activation of mitochondrial ATP sensitive $\mathrm{K}^{+}$channels $\left(\mathrm{mtK}_{\mathrm{ATP}}\right)$, resulting in the influx of $\mathrm{K}^{+}$to the mitochondrial matrix and efflux of $\mathrm{H}^{+}$. This change accelerates mitochondrial electron transport in the respiratory chain and produces more influx of electrons to the mitochondrial matrix, which in turn produces more ROS and RNS [21, 23, 33, 64, 100, 101, 107-118].

During reperfusion, the entry of oxygen and metabolic substrates in mitochondria (Figure 3 ) produces more ROS and RNS. The levels of ROS and RNS and the imminent mitochondrial membrane potential change activate the mitochondrial permeability transition pore $(\mathrm{mtPTP}), \mathrm{mtK}_{\mathrm{ATP}}$, and $\mathrm{mtK}_{\mathrm{Ca}}$ dissipating membrane potential and releasing all ROS and RNS [21, 23, 33, 64, 100, 101, 107-118].

This is known as the "point of safe return" (PSR): mitochondria have lost their membrane potential, cell activity is dampened until subsequent death, and the $I / R$ lesion has spread to contiguous cells. These contiguous cells attempt to survive injury but enter the I/R lesion state when ROS, RNS, and other molecules are released from the dying cell. It should be noted that the establishment of any therapeutic prevention must take place before PSR, with these strategies known as preconditioning. Any strategies that take place after PSR are known as postconditioning. The PSR process in mitochondria is present in all cells, but the ability to adapt to injury is tissue dependent. This is because of the high levels of oxidative stress (OS) in different tissues, and their mechanisms for adapting to sudden microenvironmental changes $[21,23,33,64,100,101,107-118]$.

\section{What Is Oxidative Stress?}

OS refers to an imbalance between the prooxidant and antioxidant levels, in favor of the prooxidants, in cells and tissues. These changes lead to modification or damage to lipids, proteins, and DNA. Prooxidants cause or promote oxidation. Antioxidants are molecules that inhibit the formation of prooxidants and inhibit oxidation [33, 66, 107, 119-126].

\section{Formation of Free Radicals}

The major source of free radicals in $\mathrm{I} / \mathrm{R}$ is mitochondria [21, $23,33,66,107,108,111,112,119-127]$. Normally, the electron transport mechanism in the mitochondrial respiratory chain 
Ischemia
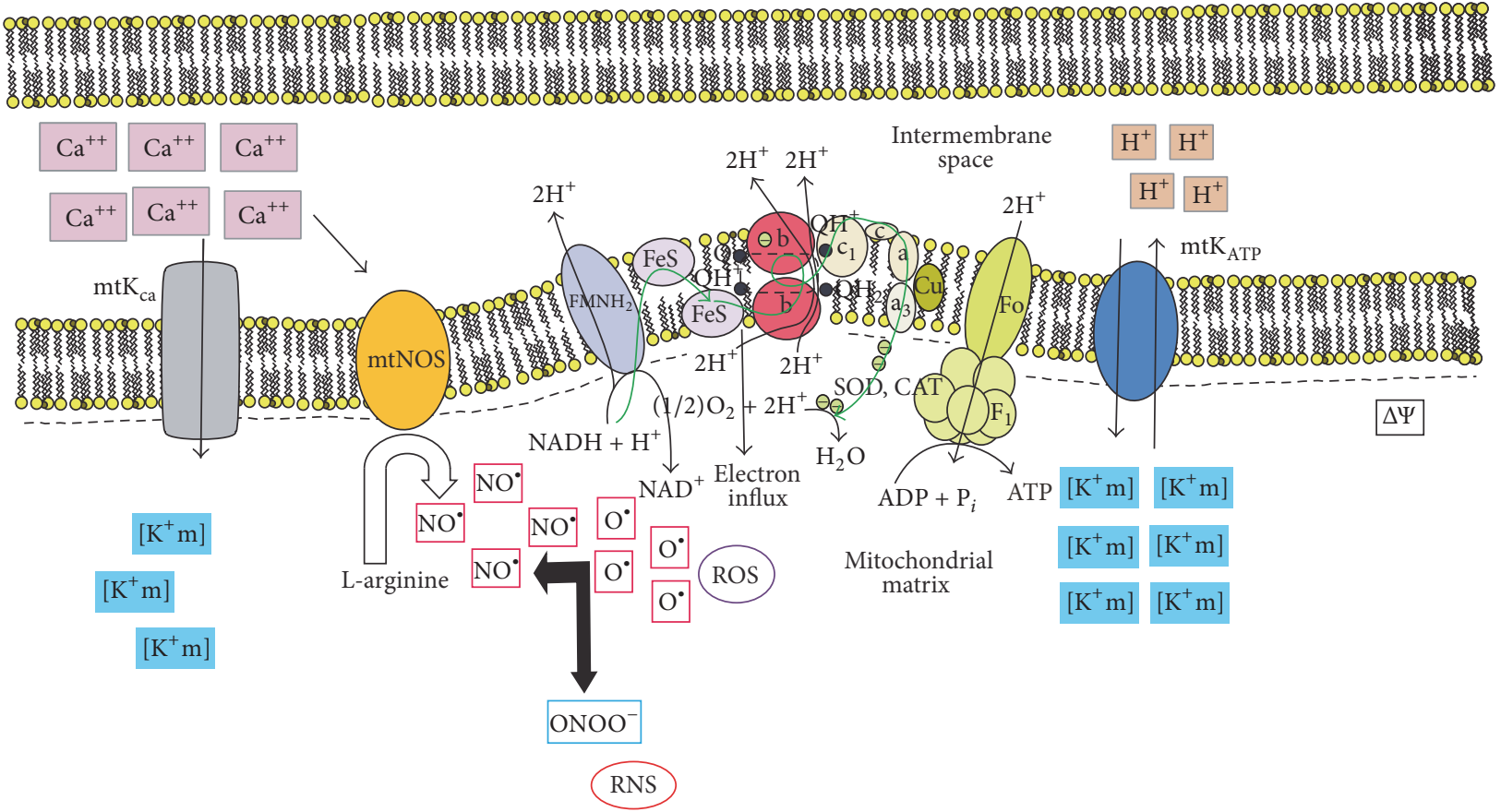

Reperfusion
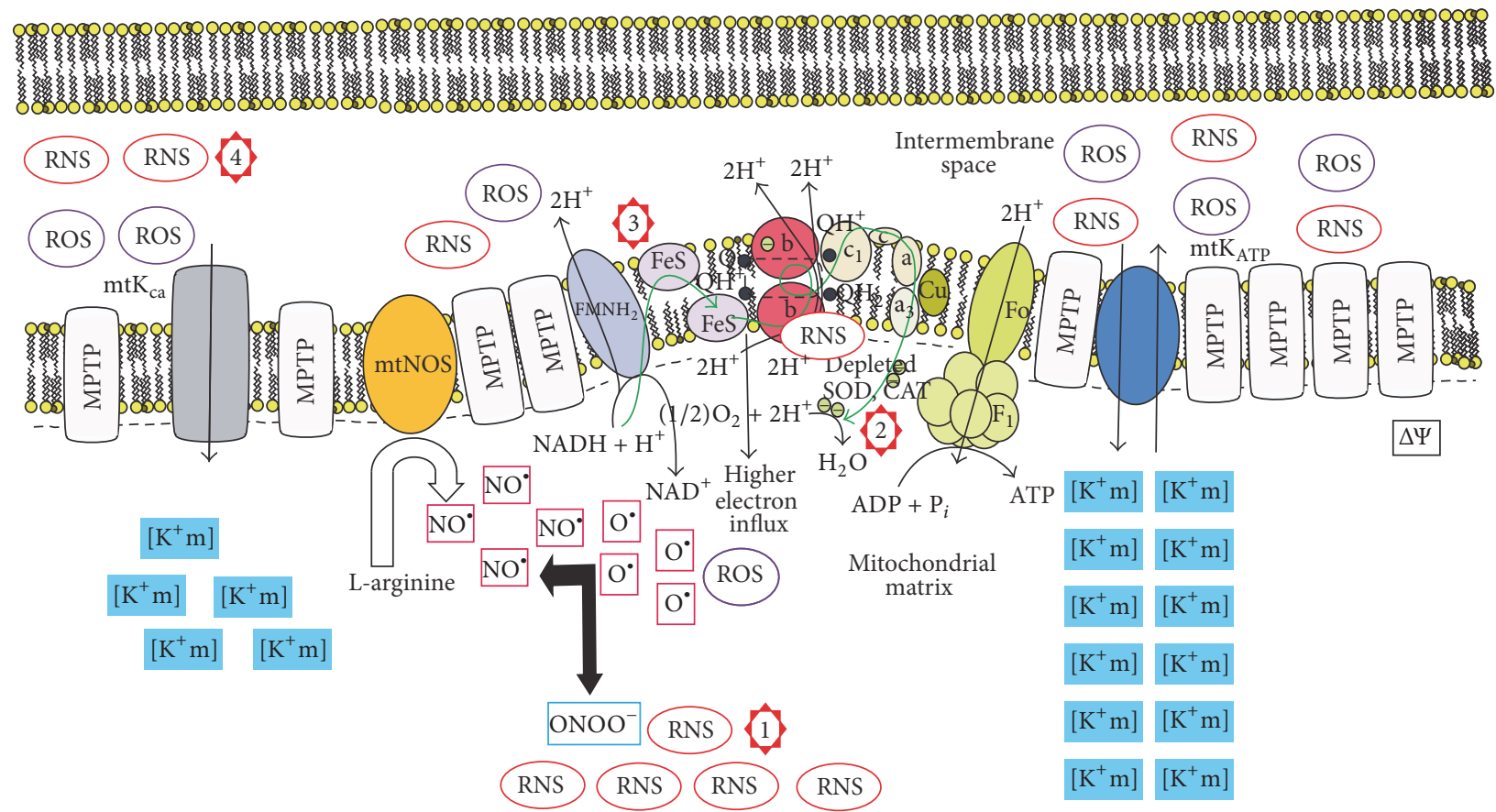

FIGURE 3: Mitochondrial I/R process. Numbers indicate the four major therapeutic points. (1) Production of ROS and RNS during I/R; (2) depletion of scavenger enzyme systems that reduce free radical; (3) overproduction of superoxide during reperfusion; (4) release and disruption of redox signaling. See the text for a more detailed description on the physiopathological processes. 


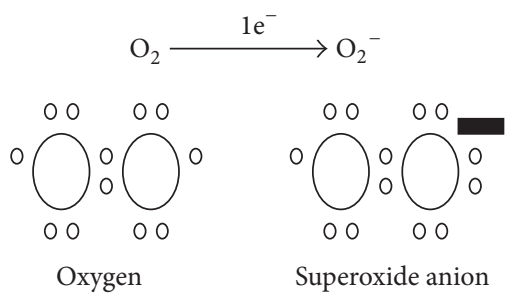

FIgURE 4: Formation of superoxide anion. The two molecules of oxygen, which are in equilibrated energetic form (6 electrons each one), accept one electron in the last orbital which leads to unstable energy form (7 and 8 electrons), making the molecule of oxygen need to take one electron from the environment to be in its energetic equilibrium form again.

is impaired, this produces ROS from one-electron reduction of oxygen (see (1)) [33, 66, 107, 119-126, 128].

$$
\mathrm{O}_{2} \underset{2 \mathrm{H}^{+}}{\stackrel{1 \mathrm{e}^{-}}{\longrightarrow}} \mathrm{O}_{2}^{-} \stackrel{1 \mathrm{e}^{-}}{\longrightarrow} \mathrm{H}_{2} \mathrm{O}_{2} \stackrel{1 \mathrm{e}^{-}}{\longrightarrow} \cdot \mathrm{OH} \stackrel{1 \mathrm{e}^{-}}{\longrightarrow} \mathrm{H}_{2} \mathrm{O}
$$

is the metabolic process of reduction of free electron. Observe the production of 4 free electrons that must be reduced to water and one diapered electron.

The lifespan of $\mathrm{O}_{2}{ }^{-}$(Figure 4) in biological systems is less than a second $(50 \mu \mathrm{s})$ and has a diffusion distance of $\sim 320 \mathrm{~nm}$. It rapidly reacts with another molecule of superoxide to form hydrogen peroxide $\left(\mathrm{H}_{2} \mathrm{O}_{2}\right)[33,66,107,119-126,129,130]$.

In mitochondria, one of the important reactions is the diffusion reaction between $\mathrm{O}_{2}{ }^{-}$with $\mathrm{NO}^{\circ}$ (termed the radicalradical reaction) (see (2)) to form $\mathrm{ONOO}^{-}$, which can diffuse across biological membranes at a 400 times greater rate than $\mathrm{O}_{2}{ }^{-}$. The half-life of $\mathrm{ONOO}^{-}$is $<0.1 \mathrm{~s}$ and it has high reactivity with organic molecules, especially lipids $[33,66$, $107,119-126,129,130]$.

$$
\mathrm{O}_{2}{ }^{-}+\mathrm{NO}^{\bullet} \longrightarrow \mathrm{ONOO}^{-}
$$

is radical to radical reaction to form peroxynitrite on one of the most instable radicals.

Under physiological states, the production of $\mathrm{O}_{2}{ }^{-}$produces $\mathrm{H}_{2} \mathrm{O}_{2}$ via manganese superoxide dismutase (MnSOD) in the mitochondrial matrix. This enzyme is found in tetramers, with each subunit consisting of 151 amino acids. MnSOD maintains the steady-state concentration of $\mathrm{O}_{2}{ }^{-}$at 10-10 M during acute phases of ischemia, but when this phase is over, the activity of MnSOD increases, which results in the production of massive levels of $\mathrm{O}_{2}{ }^{-}$that are reduced by $\mathrm{NO}^{\circ}$. Because of membrane potential, this molecule stays in the mitochondrial matrix. During reperfusion, the respiratory chain accelerates and $\mathrm{O}_{2}{ }^{-}$is overproduced. MnSOD competes with $\mathrm{NO}^{-}$to reduce the amount of $\mathrm{O}_{2}{ }^{-}$and consequently forms more $\mathrm{ONOO}^{-}$, which is released into the cytoplasm via the mtPTP $[33,66,107,119-126,129,130]$.

\section{How Free Radicals Can Cause Damage to Cells?}

The free radicals "take" one electron from the adjacent molecule, which leads to the formation of a new free radical that will "take" one electron from the adjacent molecule. Therefore, a chain reaction occurs that will only end when the free radicals are reduced by antioxidants $[25,123,125,126,128$, 130].

\section{Damage to Lipids in $I / R$}

The interaction between OS and lipids is one of the most prevalent causes of cellular injury. The degradation products of lipid peroxidation are aldehydes, such as malondialdehyde (MDA), 4-hydroxynonenal (4-HNE), and hydrocarbons such ethane and ethylene. Lipid peroxidation in mitochondria is particularly cytotoxic and has multiple effects on enzyme activity and ATP production, as well as on the initiation of apoptosis $[107,110,115,116,119,122-125,130]$.

\section{Damage to Proteins in $I / R$}

Damage to proteins occurs through site specific amino acid modifications, fragmentation of the peptide chain, aggregation of cross-linked reaction products, altered electrical charges, and increased susceptibility to removal and degradation. The activity of $\mathrm{ONOO}^{-}$produces nitrotyrosine; meanwhile $\mathrm{O}_{2}{ }^{-}$inactivates enzymatic function $[107,110,115$, $116,119,122-125,130]$.

\section{Damage to DNA in $I / R$}

OS can induce numerous lesions in DNA that cause deletions, mutations, and other lethal genetic effects. The sugar and the base fraction are susceptible to oxidation causing base degradation, single-strand breakage, and cross-linking to proteins. One product of DNA damage is 8-oxo-7,8-dihydro$2^{\prime}$-deoxyguanosine (8-Oxo-dG) $[107,110,115,116,119,122-$ $125,130]$.

\section{Pathways Affected by Redox Signaling in $\mathbf{I} / \mathbf{R}$}

Redox signaling describes the action of ROS and RNS on altering intrinsic cellular activity. At low concentrations ROS and RNS work as signaling molecules, while at high concentrations they damage multiple structures, especially mitochondria [23-25, 67, 119, 122, 129, 131].

The mechanism by which OS alters protein function and structure involves redox-reactive cysteine residues on proteins. Oxidation of these residues forms reactive sulfenic acid, which in turn forms disulphide bonds with nearby cysteines, and undergoes further oxidation into sulfinic or sulfonic acid, or sulfenamide when nitrogen is present locally. These redox modifications are reversible through reducing systems such as thioredoxin and peroxiredoxin [23-25, 67, $119,122,129,131]$.

\section{The Mitogen-Activated Protein Kinase Cascade in I/R}

The mitogen-activated protein kinase (MAPK) cascade consists of a three-rung kinase tier. The canonical cascade occurs 
when MAPK kinase kinases (MAPKKK) phosphorylate and activate MAPK kinases (MAPKK), which phosphorylate and activate MAPKs [23, 132-139].

There are two noncanonical pathways: the apoptosis signal-regulated kinase 1 (ASK1) pathway and cGMP-dependent protein kinase (PKG) pathway. In the former MAPK cascade, ASK1 is an upstream MAPKKK that regulates c-Jun $\mathrm{N}$-terminal kinases (JNK) and p38 kinase (p38), leading to apoptosis via phosphorylation of MKK4, MKK3, and MKK6 MAPKKs. ASK1 is activated by OS and mediates p38 signaling, which leads to differentiation and immune signaling. However, activation of ASK1 by high levels of OS (via oxidization of two cysteine residues in the redox center of thioredoxin) induces ASK1 dissociation and allows its complete oligomerization with tumor necrosis factor- $\alpha$ receptor associated factor (TRAF) and ASK2, thereby promoting cell death. Alternatively, the PKG pathway is integrated by PKG1 $\alpha$, protein kinase A (PKA), and protein kinase $\mathrm{C}(\mathrm{PKC})$ and, similarly, is also regulated by a redox mechanism [23, 132-139].

\section{The Phosphoinositide 3-Kinase Signaling Pathway in I/R}

Phosphoinositide 3-kinase (PI3K) consists of one catalytic (p110) and one regulatory (p85) subunit and is firmly coupled with the receptor tyrosine kinase (RTK) family, which are activated by several growth factors. PI3K catalyzes phosphatidylinositol 4,5-diphosphate (PIP2) to synthesize the second messenger, phosphatidylinositol 3,4,5-triphosphate (PIP3). PIP3 serves as a membrane-bound signaling molecule that recruits proteins containing pleckstrin homology $(\mathrm{PH})$ domains, such as phosphoinositide-dependent protein kinase (PDK) and protein kinase B (AKT) serine threonine/kinase, which mediate further downstream signaling events. Phosphatase and tensin homolog (PTEN) phosphorylates PIP3, causing inhibition and ensuring that the PI3K pathway is subject to reversible redox regulation by OS. Oxidation of PTEN by OS leads to persistent activation of the PI3K pathway, causing permanent activation of RTKs [14, 19, 134, $140-146]$.

\section{The Redox Factor-1 and NF-E2-Like 2 (Nuclear Factor Erythroid 2) Pathway in $\mathbf{I} / \mathbf{R}$}

Redox factor-1 (Ref-1) is a multifunctional protein that regulates transcription factor activity and also mediates base excision repair. The transcriptional regulatory function of Ref- 1 is exerted by its redox activity on several transcription factors, including activator protein 1 (AP-1), p53, nuclear factor kappa B (NF- $\kappa$ B), and hypoxia inducible factor 1 (HIF1).

Ref-1 activates the AP-1-Fos-Jun complex via redox regulation of cysteine residues in Fos-Jun DNA binding domains. As it mediates both DNA repair and redox activation of key transcription factors involved in cellular defense (including AP-1 and NF- $\kappa$ B), upregulated Ref- 1 activity protects DNA from oxidative damage. Consequently, OS conditions can activate detoxification genes such as glutathione $S$-transferase (GST), NADPH quinone oxidoreductase-1 (NQO1), heme oxygenase-1 (HO1), and ferritin $\mathrm{H}(\mathrm{FH})[23-25,67,119,122$, $129,131]$.

NF-E2-like 2 (Nrf2) is another transcription factor, which activates antioxidant responsive element- (ARE-) dependent transcription of target genes under OS. These genes serve as antioxidants in processes such as electrophile detoxification, glutathione synthesis, and ROS homeostasis [23-25, 67, 119, $122,129,131,147]$.

The interaction between these two pathways has a protective, synergistic effect against OS. During I/R, Ref-1 and Nrf2 upregulation increases expression of NF- $\kappa \mathrm{B}$, which increases apoptosis and inflammation $[23-25,67,119,122,129,131,147$, 148].

\section{Transcriptional Reprograming in $I / R$}

The alteration in transcriptional control of gene expression induced by $\mathrm{I} / \mathrm{R}$ lesions is known as transcriptional reprograming. Oxygen depletion and increased ROS, RNS, and apoptosomes lead to transcriptional alterations within the nucleus. Damage (secondary to redox signaling disruption) causes toll-like receptor (TLR) expression in the membrane of affected cells, indirectly affects NF- $\kappa \mathrm{B}$ expression, and increases MAPK and interferon activity. TLR3 is overexpressed in necrotic cells, TLR2 is overexpressed in hypoxic and inflammatory states, while TLR4 is exclusively overexpressed in renal I/R lesions. During the process of adaption, cells affected by $\mathrm{I} / \mathrm{R}$ lesions show specific expression of microRNAs (miRNAs), which modulate gene expression through transcriptional and posttranscriptional pathways. For example, miRNA-21 blocks PTEN expression in the ischemic state and reduces apoptosis in the first $48 \mathrm{~h}$ but shows persistent overexpression during this time and subsequently increases apoptosis as a result of PTEN reduction. Moreover, miRNA378 blocks caspase- 3 expression and reduces apoptosis in the reperfusion state. Expression of multiple genes depends on the amount of OS, time of ischemia, and number of necrotic cells produced during ischemia $[10,11,19,22,23,93,98,132-$ $139,149-170]$.

\section{Apoptosis, Autophagy, and Necrosis in $I / R$}

The process of cellular destruction starts after mitochondrial lesion, disruption of redox signaling, and transcriptional reprograming. During apoptosis and after PSR is reached, the mtPTP releases cytochrome $\mathrm{C}$ from the membrane, activating the caspase cascade and pannexin hemichannels, which release ATP and work as beacons for phagocytic cells. Redox signaling disruption and transcriptional reprograming lead to NF- $\kappa \mathrm{B}$ activation, which activates apoptosis and is histologically characterized by nuclear fragmentation, endosome formation, mitochondrial and cellular contraction, and loss of membrane potential. Autophagy is also produced as an adaptive response to sublethal OS, with metabolic change and transcriptional survival reprograming in endosomes, loss of organelles, and formation of coil-shaped vacuoles 
observed. Cell damage can progress to necrosis, with or without the presence of edema within cells and organelles, or cause cell membrane disruption and efflux of enzymes to the extracellular space $[10,11,19,22,23,93,98,132-139,149-176]$.

\section{Immunity-Mediated Lesions in $I / R$}

During the I/R lesion, three pathways are activated: sterile inflammation, adaptive response, and innate autoimmunity. Sterile inflammation is mediated by TLRs, which lead to NF- $\kappa \mathrm{B}, \mathrm{MAPK}$, and interferon activation. These receptors also produce chemotaxis of inflammatory and phagocytic cells, which start the inflammatory response. After $24 \mathrm{~h}$ of reperfusion, the adaptive response begins, with expansion and recruitment of $\mathrm{T}$ cells. At $72 \mathrm{~h}$, the highest level of response and $\mathrm{T}_{\text {reg }}$ depletion is reached. This affects the innate response, leading to autoimmunity characterized by autoantibody formation by B cells, complement activation, and $\mathrm{Bcl} 3$ depletion, which inhibits granulopoiesis production $[10,11,22,97,152,177-180]$.

\section{Endothelial Lesion}

Endothelial lesions that present during the ischemic state are principally affected by decreased oxygen, increased ROS and RNS, and redox signaling disruption, followed by membrane potential loss and increasing membrane permeability, chemotaxis, and imbalanced capillary vasoconstriction/vasodilatation factors. In the reperfusion state, the endothelium suffers lesions caused by the immune response and activation of the coagulation system, increasing leucocitary adherence, and platelet-leucocitary interaction. This process is produced by mechanical brushing that occurs in the damaged endothelium and causes e-selectin adherence protein expression in the membrane, which interacts with the ligand, selectin-1, and in neutrophils coactivates integrin$\alpha \mu \beta 2$. Following interaction and formation of this complex, neutrophils are able to bind to erythrocytes and platelets through their membrane, which directs them to the damaged tissue and increases the inflammatory response in affected tissue $[10,11,22,117,127,180,181]$.

\section{No Reflow Phenomenon}

The no reflow phenomenon is present in the reperfusion state because of endothelial cell injury, activation of the coagulation process, and increased leucocitary adherence. This phenomenon increases impedance of microvascular flow and capillary occlusion by leucocytes and is present in $60 \%-68 \%$ of all I/R cases [9-11, 22, 91, 182].

\section{Analysis of the Pharmacological Approach in I/R}

The actual pharmacological approach to prevent or mitigate $\mathrm{I} / \mathrm{R}$ lesions has so far been unsuccessful. This is likely because one drug cannot cure all disturbances, and, indeed, the phenomenon is a result of several events that follow a specific sequence. Consequently, attempting to cover the physiopathological process with just one medication is likely not enough. Most studies have attempted to show that one drug will make a difference, and regarding I/R lesion in vitro experiments and preclinical studies have shown good results. Nonetheless, the lesion is manifested systemically and affects several processes; therefore, the correct approach needs several drugs targeting the physiopathological process (Figure 3) [1-3, 55, 64, 65, 75, 92, 94, 95, 100, 104, 183-185].

\section{The Gender Aspect of $I / R$}

Recent studies dealing with survival in specific pathological conditions related to $I / R$ have shown significantly better patient survival in females than males. However, other studies have shown a much poorer outcome associated with female patients. The reason for these controversial results is not clear, but a variety of different factors may influence interpretation of these studies. For example, age (postmenopausal), race, underlying disease, and/or medications may impact the outcome. Failure to account for and control these different variables makes it difficult to accurately assess the role of gender in reducing or increasing survival expectancy following I/R lesions [186-191].

\section{The Physiopathological Approach}

The critical points in $\mathrm{OS}$ in $\mathrm{I} / \mathrm{R}$ are the production of prooxidants, the depletion of SOD, the accumulation of free radicals, loss of mitochondrial membrane potential with subsequent release from mitochondria, and redox signaling disruption. There are several drugs that may have therapeutic potential (Table 1).

\section{Electron Acceptor}

The process of reducing free radicals is made possible based on the structure of the molecules. These drugs are equipped by one or more aromatic ring with hydroxyl groups in their structures. Therefore, they can exchange the free radical with the hydroxyl group and end the chain reaction of free radical accumulation. The structure of curcumin and cannabidiol (Figure 5) has a typical antioxidant architecture that confers no enzymatic scavenging ability $[24,26-29,33-$ $35]$. Besides, the cannabidiol in the liver and cardiac I/R lesion has shown that it could interact directly with the cannabinoid $\mathrm{CB}_{2}$ receptor. In the heart the agonism of the $\mathrm{CB}_{2}$ receptor was shown to modulate the myocardial inflammation and attenuates the infarct size (142) and decreases the myocardial ROS and RNS generation, restores the glutathione content and SOD activity, and modulates the signaling redox and the NF- $\kappa$ B activation (143). In the liver the cannabidiol attenuates tissue oxidative and nitrative stress, acute and chronic hepatic inflammatory response, signaling redox, and cell death by its strong antioxidant ability and the interaction with the $\mathrm{CB}_{2}$ receptor (144).

\section{Block of Mitochondrial Respiratory Chain Complex I}

Complex I in the mitochondrial respiratory chain is the most important for the production of $\mathrm{O}_{2}^{-}$, which is produced by 
TABLE 1: Promising drugs in the I/R lesion.

\begin{tabular}{|c|c|c|c|c|c|}
\hline Drug & $\begin{array}{l}\text { Molecular } \\
\text { mechanism }\end{array}$ & Beneficial effect in IR & Adverse effects & $\begin{array}{l}\text { Organ cell } \\
\text { major effect }\end{array}$ & $\begin{array}{c}\text { Literature } \\
\text { support study }\end{array}$ \\
\hline Curcumin & $\begin{array}{l}\text { Electron } \\
\text { acceptor }\end{array}$ & $\begin{array}{l}\text { Reduction of free } \\
\text { radicals }\end{array}$ & $\begin{array}{l}\text { Dermatitis } \\
\text { Bitter taste }\end{array}$ & Neurons & {$[26-32]$} \\
\hline Cannabidiol & $\begin{array}{l}\text { Electron } \\
\text { acceptor }\end{array}$ & $\begin{array}{l}\text { Reduction of free } \\
\text { radicals, modulation } \\
\text { of inflammation and } \\
\text { signaling redox }\end{array}$ & Neuronal disorders & $\begin{array}{c}\text { Neurons } \\
\text { Hepatocyte } \\
\text { Cardiomyocyte }\end{array}$ & {$[24,33-43]$} \\
\hline Metformin & $\begin{array}{l}\text { Block of complex I in } \\
\text { respiratory chain }\end{array}$ & $\begin{array}{l}\text { Modulated } \\
\text { production of free } \\
\text { radicals }\end{array}$ & $\begin{array}{c}\text { Lactic acidosis } \\
\text { Blood coagulation } \\
\text { disorder } \\
\text { Liver function test } \\
\text { abnormal } \\
\text { Encephalopathy }\end{array}$ & $\begin{array}{l}\text { Hepatocyte } \\
\text { Cardiomyocyte } \\
\text { Neurons }\end{array}$ & {$[44-52]$} \\
\hline Pioglitazone & ${ }^{*}$ PPAR- $\gamma$ agonist & $\begin{array}{l}\text { Increments on the } \\
\text { expression of } \\
{ }^{* *} \text { MnSOD and some } \\
\text { other survival gens }\end{array}$ & $\begin{array}{l}\text { Congestive heart } \\
\text { failure } \\
\text { Edema } \\
\text { Liver function test } \\
\text { abnormal } \\
\text { Osteopenia }\end{array}$ & $\begin{array}{c}\text { Endothelial cells } \\
\text { Cardiomyocyte } \\
\text { Hepatocyte }\end{array}$ & {$[50-63]$} \\
\hline Atorvastatin & Pleiotropic effects & $\begin{array}{l}\text { Reduction of free } \\
\text { radicals, increments } \\
\text { on expression of } \\
\text { MnSOD, modulation } \\
\text { of survival gens }\end{array}$ & $\begin{array}{l}\text { Diabetes mellitus } \\
\text { Reduction of } \\
\text { ubiquinone level } \\
\text { Liver function test } \\
\text { abnormal } \\
\text { Autoimmune disease } \\
\text { Rhabdomyolysis } \\
\text { Acute kidney injury }\end{array}$ & $\begin{array}{c}\text { Endothelial cells } \\
\text { Cardiomyocyte } \\
\text { Hepatocyte } \\
\text { Musculoskeletal }\end{array}$ & $\begin{array}{c}{[30-32,64-} \\
74]\end{array}$ \\
\hline Telmisartan & Pleiotropic effects & $\begin{array}{l}\text { Reduction of free } \\
\text { radicals, increments } \\
\text { on expression of } \\
\text { MnSOD, modulation } \\
\text { of survival gens }\end{array}$ & $\begin{array}{l}\text { Angina pectoris } \\
\text { Edema } \\
\text { Carcinogen effect } \\
\text { Liver function test } \\
\text { abnormal }\end{array}$ & $\begin{array}{c}\text { Endothelial cells } \\
\text { Cardiomyocyte } \\
\text { Hepatocyte }\end{array}$ & {$[58,75-90]$} \\
\hline
\end{tabular}

${ }^{*}$ PPAR- $\gamma$ : peroxisome proliferator activated receptor- $\gamma \cdot{ }^{* *}$ MnSOD: manganese superoxide dismutase.<smiles>COc1cc(/C=C/C(=O)CC(=O)/C=C/c2ccc(O)c(OC)c2)ccc1O</smiles>

Curcumin<smiles>C=C(C)c1ccc(C)cc1-c1c(O)cc(CCCCC)cc1O</smiles>

Cannabidiol

FIGURE 5: Structure of curcumin and cannabidiol, with properties to interact with free radicals in their proximity.

the reverse transport of electrons from complex II. During the ischemic phase, the partial disablement of this primary component results in free radical formation because of the strain it has on the electron transport to complex III, and, during the reperfusion phase, the production of $\mathrm{O}_{2}{ }^{-}$is attenuated $[36-38,44]$. One of the actions of complex I inhibitor metformin is to induce mild and specific inhibition of mitochondrial respiratory chain complex I, which reduces free radical formation [44].

\section{Peroxisome Proliferator Activated Receptor- $\gamma$ (PPAR- $\gamma$ ) Agonist}

This class II nuclear receptor interacts with multiple survivor genes and can down- or upregulate proteins involved in the tolerance to I/R injury. Normally, PPAR- $\gamma$ works as a heterodimer with retinal receptor but interacts with multiple response systems in the DNA; activation of this receptor can increase the expression of MnSOD and other enzymatic 
scavengers and blocks the induction of apoptosis. The PPAR$\gamma$ agonists pioglitazone and telmisartan increase the bioavailability and action of PPAR- $\gamma$ to improve cell survival [45$47,53-55,76-78,192-194]$.

\section{Pleiotropic Effects}

There are multiple pathways involved in the production of OS that can be modulated, and several in vitro studies and animal models have shown promising results. In vitro experiments using atorvastatin have shown a reduction in ROS and RNS levels in I/R and various injury models including degenerative pathologies and chronic diseases. In addition, atorvastatin was shown to activate nuclear receptors such PPAR- $\gamma$. Telmisartan has a similar effect and reduces OS by activating PPAR- $\gamma$, blocking the angiotensin II receptor, type 1 (AT1 receptor), increasing levels of enzymatic scavengers, and activating cell survival pathways [45-47, 53-58, 65-68, 76-78, 192-194].

\section{Prejudice in the Physiopathological Approach}

The adverse effect of drugs may influence the therapeutic effect, with possibly the most questionable drugs being atorvastatin (statins) and pioglitazone (PPAR- $\gamma$ agonist). The atorvastatin controversy owes to the associated increased risk of diabetes mellitus, with a meta-analysis showing that, after at least 4 years of treatment, patients have an incidence of 5\%-6\% for diabetes mellitus onset and decrease in serum ubiquinone levels of $32 \%-54 \%$ during statin use for at least three months. However, treatment for I/R lesions last for only a short period of time and should be administered during the first hours of diagnosis and for not longer than two weeks, to reduce the chance of suffering major adverse effects. It is well known that pioglitazone should not be used in class II or III New York Heart Association heart failure scale patients, or those with a depressed ejection fraction of less than $40 \%$, due to exacerbation of congestive heart failure (approximately 9\%) in studies when the treatment time lasted from 3 weeks to 3 months using the maximal recommended dose. Treatment with pioglitazone for I/R lesions should not surpass the recommended dose or last longer than two weeks, as mentioned above.

\section{Future Prospects}

Several attempts have been made to inhibit $\mathrm{I} / \mathrm{R}$ lesions, but the real challenge lies in attenuating the processes that lead to the formation of lesions, which include the mitochondrial production of ROS and RNS and disruption of signaling redox. To date, most research has focused on the inflammatory response [96, 97], and there is limited knowledge on the effect of preconditioning, postconditioning, and remote ischemic preconditioning. The most studied therapeutic approaches with respect to I/R lesions are the mechanical process of preconditioning, postconditioning, and remote preconditioning $[1,2,10,12,13,15-18,20,21$, $64,92,93,108,109,114,118,142,195-204]$; however, the results are controversial, and the greatest benefits have only been observed in animal models [2, 10, 64, 197]. In addition, meta-analysis and randomized trials have shown that this procedure has no beneficial effect on mortality but can improve periprocedural myocardial infarction and afford some neuroprotection [196, 203, 204]. However, it should be noted that this procedure needs to be performed within a strict timeframe and is dependent on the condition of the patient. Therefore, not all patients are suitable candidates. To complicate matters, the heterogeneity of injury also limits the effectiveness of this method. These variables have biased the statistical evaluation of this approach. Nevertheless, no one has implemented a pharmacological regimen for the management of OS, before, during, or after the procedure despite all the evidence for the involvement of OS.

\section{Conclusion}

OS in I/R lesions has a big impact on the activation of multiple secondary mechanisms of damage. Therefore, the search for a therapeutic pharmacological regimen that can inhibit the production of ROS and RNS and can modulate the signaling redox should take priority in the treatment of I/R lesions. There are currently no studies on pharmacological regimens at any institution or clinical trials for patients who suffer the $\mathrm{I} / \mathrm{R}$ phenomenon in combination with other strategies of mechanical procedure. The establishment of new animal models and studies focusing on the mechanism of action of known drugs that have been used for other pathological states has revealed that reducing OS can provide beneficial outcomes. Perhaps combination therapy could attenuate OS further and provide a better prognosis for patients who suffer from this phenomenon following mechanical procedures. There is no sufficient data to confirm or reject this hypothesis. Therefore, more studies should be performed to determine a standardized therapeutic regimen to control or prevent the OS damage in I/R before, during, and after mechanical procedures.

\section{Competing Interests}

The authors declare that they have no competing interests.

\section{References}

[1] C. E. Murry, R. B. Jennings, and K. A. Reimer, "Preconditioning with ischemia: a delay of lethal cell injury in ischemic myocardium," Circulation, vol. 74, no. 5, pp. 1124-1136, 1986.

[2] R. B. Jennings, "Historical perspective on the pathology of myocardial ischemia/reperfusion injury," Circulation Research, vol. 113, no. 4, pp. 428-438, 2013.

[3] A. T. Turer and J. A. Hill, "Pathogenesis of myocardial ischemiareperfusion injury and rationale for therapy," The American Journal of Cardiology, vol. 106, no. 3, pp. 360-368, 2010.

[4] V. L. Roger, A. S. Go, D. M. Lloyd-Jones et al., "Executive summary: heart disease and stroke statistics-2012 update: a report from the American Heart Association," Circulation, vol. 125, no. 1, pp. 188-197, 2012.

[5] C. Cantú-Brito, J. L. Ruiz-Sandoval, L. M. Murillo-Bonilla et al., "Acute care and one-year outcome of Mexican patients 
with first-ever acute ischemic stroke: The PREMIER study," Revista de Neurologia, vol. 51, no. 11, pp. 641-649, 2010.

[6] R. G. Guzmán and J. A. Ramírez, Enfermedad Isquémica del Corazón, Epidemiología y Prevención, 2010.

[7] M. N. Á. Saldivar, A. E. O. Cruz, and H. J. R. Flores, "Enfermedad vascular cerebral: incidencia y factores de riesgo en el Hospital General La Perla," Medicina Interna de México, vol. 28, no. 4, p. 342, 2012.

[8] R. Lozano, H. Gómez-Dantés, F. Garrido-Latorre et al., "La carga de enfermedad, lesiones, factores de riesgo y desafíos para el sistema de salud en México," Salud Pública de México, vol. 55, no. 6, pp. 580-594, 2013.

[9] H. K. Eltzschig and T. Eckle, "Ischemia and reperfusion-from mechanism to translation," Nature Medicine, vol. 17, no. 11, pp. 1391-1401, 2011.

[10] M. T. Dirksen, G. J. Laarman, M. L. Simoons, and D. J. G. M. Duncker, "Reperfusion injury in humans: a review of clinical trials on reperfusion injury inhibitory strategies," Cardiovascular Research, vol. 74, no. 3, pp. 343-355, 2007.

[11] G. J. Gross and J. A. Auchampach, "Reperfusion injury: does it exist?" Journal of Molecular and Cellular Cardiology, vol. 42, no. 1, pp. 12-18, 2007.

[12] Z.-Q. Zhao and J. Vinten-Johansen, "Postconditioning: reduction of reperfusion-induced injury," Cardiovascular Research, vol. 70, no. 2, pp. 200-211, 2006.

[13] Z.-Q. Zhao, J. S. Corvera, M. E. Halkos et al., "Inhibition of myocardial injury by ischemic postconditioning during reperfusion: comparison with ischemic preconditioning," American Journal of Physiology-Heart and Circulatory Physiology, vol. 285, no. 2, pp. H579-H588, 2003.

[14] L. Zhao, J. Y. Lee, and D. H. Hwang, “The phosphatidylinositol 3-kinase/Akt pathway negatively regulates Nod2-mediated NF$\kappa \mathrm{B}$ pathway," Biochemical Pharmacology, vol. 75, no. 7, pp. 1515$1525,2008$.

[15] H. Zhao, "Ischemic postconditioning as a novel avenue to protect against brain injury after stroke," Journal of Cerebral Blood Flow and Metabolism, vol. 29, no. 5, pp. 873-885, 2009.

[16] J. Vinten-Johansen, Z.-Q. Zhao, R. Jiang, A. J. Zatta, and G. P. Dobson, "Preconditioning and postconditioning: innate cardioprotection from ischemia-reperfusion injury," Journal of Applied Physiology, vol. 103, no. 4, pp. 1441-1448, 2007.

[17] H. Kin, Z.-Q. Zhao, H.-Y. Sun et al., "Postconditioning attenuates myocardial ischemia-reperfusion injury by inhibiting events in the early minutes of reperfusion," Cardiovascular Research, vol. 62, no. 1, pp. 74-85, 2004.

[18] P. Staat, G. Rioufol, C. Piot et al., "Postconditioning the human heart," Circulation, vol. 112, no. 14, pp. 2143-2148, 2005.

[19] Y. Tu, L. Wan, Y. Fan et al., "Ischemic postconditioningmediated miRNA-21 protects against cardiac ischemia/reperfusion injury via PTEN/Akt pathway," PLoS ONE, vol. 8, no. 10, Article ID e75872, 2013.

[20] C. Penna, D. Mancardi, S. Raimondo, S. Geuna, and P. Pagliaro, "The paradigm of postconditioning to protect the heart," Journal of Cellular and Molecular Medicine, vol. 12, no. 2, pp. 435458, 2008.

[21] T. Kalogeris, Y. Bao, and R. J. Korthuis, "Mitochondrial reactive oxygen species: a double edged sword in ischemia/reperfusion vs preconditioning," Redox Biology, vol. 2, no. 1, pp. 702-714, 2014.

[22] T. Kalogeris, C. P. Baines, M. Krenz, and R. J. Korthuis, "Cell biology of ischemia/reperfusion injury," International Review of Cell and Molecular Biology, vol. 298, pp. 229-317, 2012.
[23] C. H. Foyer and G. Noctor, "Redox sensing and signalling associated with reactive oxygen in chloroplasts, peroxisomes and mitochondria," Physiologia Plantarum, vol. 119, no. 3, pp. 355-364, 2003.

[24] C. Lipina and H. S. Hundal, "Modulation of cellular redox homeostasis by the endocannabinoid system," Open Biology, vol. 6, no. 4, Article ID 150276, 2016.

[25] D. Trachootham, W. Lu, M. A. Ogasawara, N. R.-D. Valle, and P. Huang, "Redox regulation of cell survival," Antioxidants and Redox Signaling, vol. 10, no. 8, pp. 1343-1374, 2008.

[26] A. Barzegar and A. A. Moosavi-Movahedi, "Intracellular ROS protection efficiency and free radical-scavenging activity of curcumin," PLoS ONE, vol. 6, no. 10, Article ID e26012, 2011.

[27] A. B. Kunnumakkara, P. Anand, and B. B. Aggarwal, "Curcumin inhibits proliferation, invasion, angiogenesis and metastasis of different cancers through interaction with multiple cell signaling proteins," Cancer Letters, vol. 269, no. 2, pp. 199-225, 2008.

[28] U. Singh, A. Barik, B. G. Singh, and K. I. Priyadarsini, "Reactions of reactive oxygen species (ROS) with curcumin analogues: structure-activity relationship," Free Radical Research, vol. 45, no. 3, pp. 317-325, 2011.

[29] P. K. Sood, U. Nahar, and B. Nehru, "Curcumin attenuates aluminum-induced oxidative stress and mitochondrial dysfunction in rat brain," Neurotoxicity Research, vol. 20, no. 4, pp. 351-361, 2011.

[30] J. Li, Y.-M. Sun, L.-F. Wang, Z.-Q. Li, W. Pan, and H.-Y. Cao, "Comparison of effects of simvastatin versus atorvastatin on oxidative stress in patients with coronary heart disease," Clinical Cardiology, vol. 33, no. 4, pp. 222-227, 2010.

[31] J. Wang, J. Xu, C. Zhou et al., "Improvement of arterial stiffness by reducing oxidative stress damage in elderly hypertensive patients after 6 months of atorvastatin therapy," Journal of Clinical Hypertension, vol. 14, no. 4, pp. 245-249, 2012.

[32] J. Yang, C. Liu, L. Zhang et al., "Intensive atorvastatin therapy attenuates the inflammatory responses in monocytes of patients with unstable angina undergoing percutaneous coronary intervention via peroxisome proliferator-activated receptor $\gamma$ activation," Inflammation, vol. 38, no. 4, pp. 1415-1423, 2015.

[33] P. Kovacic, R. Somanathan, and M. Abadjian, "Natural monophenols as therapeutics, antioxidants and toxins; electron transfer, radicals and oxidative stress," The Natural Products Journal, vol. 5, no. 3, pp. 142-151, 2015.

[34] R. S. Borges, J. Batista Jr., R. B. Viana et al., "Understanding the molecular aspects of tetrahydrocannabinol and cannabidiol as antioxidants," Molecules, vol. 18, no. 10, pp. 12663-12674, 2013.

[35] P. Kovacic and R. Somanathan, "Cannabinoids (CBD, CBDHQ and THC): metabolism, physiological effects, electron transfer, reactive oxygen species and medical use," The Natural Products Journal, vol. 4, no. 1, pp. 47-53, 2014.

[36] R. Durst, H. Danenberg, R. Gallily et al., "Cannabidiol, a nonpsychoactive Cannabis constituent, protects against myocardial ischemic reperfusion injury," American Journal of Physiology-Heart and Circulatory Physiology, vol. 293, no. 6, pp. H3602-H3607, 2007.

[37] M. Rajesh, P. Mukhopadhyay, S. Bátkai et al., "Cannabidiol attenuates cardiac dysfunction, oxidative stress, fibrosis, and inflammatory and cell death signaling pathways in diabetic cardiomyopathy," Journal of the American College of Cardiology, vol. 56, no. 25, pp. 2115-2125, 2010.

[38] P. Mukhopadhyay, M. Rajesh, B. Horváth et al., "Cannabidiol protects against hepatic ischemia/reperfusion injury by attenuating inflammatory signaling and response, oxidative/nitrative 
stress, and cell death," Free Radical Biology and Medicine, vol. 50, no. 10, pp. 1368-1381, 2011.

[39] N. D. Volkow, R. D. Baler, W. M. Compton, and S. R. B. Weiss, "Adverse health effects of marijuana use," The New England Journal of Medicine, vol. 370, no. 23, pp. 2219-2227, 2014.

[40] O. Devinsky, M. R. Cilio, H. Cross et al., "Cannabidiol: pharmacology and potential therapeutic role in epilepsy and other neuropsychiatric disorders," Epilepsia, vol. 55, no. 6, pp. 791802, 2014.

[41] C. Hindocha, T. P. Freeman, G. Schafer et al., "Acute effects of delta-9-tetrahydrocannabinol, cannabidiol and their combination on facial emotion recognition: a randomised, doubleblind, placebo-controlled study in cannabis users," European Neuropsychopharmacology, vol. 25, no. 3, pp. 325-334, 2015.

[42] J. M. McPartland, M. Duncan, V. Di Marzo, and R. G. Pertwee, "Are cannabidiol and $\Delta$ 9-tetrahydrocannabivarin negative modulators of the endocannabinoid system? A systematic review," British Journal of Pharmacology, vol. 172, no. 3, pp. 737753, 2015.

[43] A. W. Zuardi, J. A. S. Crippa, J. E. C. Hallak et al., "A critical review of the antipsychotic effects of cannabidiol: 30 years of a translational investigation," Current Pharmaceutical Design, vol. 18, no. 32, pp. 5131-5140, 2012.

[44] H. R. Bridges, A. J. Y. Jones, M. N. Pollak, and J. Hirst, "Effects of metformin and other biguanides on oxidative phosphorylation in mitochondria," Biochemical Journal, vol. 462, no. 3, pp. 475487, 2014.

[45] D. A. Kane, E. J. Anderson, J. W. Price et al., "Metformin selectively attenuates mitochondrial $\mathrm{H} 2 \mathrm{O} 2$ emission without affecting respiratory capacity in skeletal muscle of obese rats," Free Radical Biology and Medicine, vol. 49, no. 6, pp. 1082-1087, 2010.

[46] B. Viollet, B. Guigas, N. Sanz Garcia, J. Leclerc, M. Foretz, and F. Andreelli, "Cellular and molecular mechanisms of metformin: an overview," Clinical Science, vol. 122, no. 6, pp. 253-270, 2012.

[47] W. W. Wheaton, S. E. Weinberg, R. B. Hamanaka et al., "Metformin inhibits mitochondrial complex I of cancer cells to reduce tumorigenesis," eLife, vol. 2014, no. 3, Article ID e02242, 2014.

[48] S. E. Inzucchi, K. J. Lipska, H. Mayo, C. J. Bailey, and D. K. McGuire, "Metformin in patients with type 2 diabetes and kidney disease: a systematic review," The Journal of the American Medical Association, vol. 312, no. 24, pp. 2668-2675, 2014.

[49] M.-E. Lautatzis, D. G. Goulis, and M. Vrontakis, "Efficacy and safety of metformin during pregnancy in women with gestational diabetes mellitus or polycystic ovary syndrome: a systematic review," Metabolism: Clinical and Experimental, vol. 62, no. 11, pp. 1522-1534, 2013.

[50] C. L. Morgan, J. Mukherjee, S. Jenkins-Jones, S. E. Holden, and C. J. Currie, "Combination therapy with metformin plus sulphonylureas versus metformin plus DPP-4 inhibitors: association with major adverse cardiovascular events and all-cause mortality," Diabetes, Obesity and Metabolism, vol. 16, no. 10, pp. 977-983, 2014.

[51] A. Nakano, Y. Hattori, C. Aoki, T. Jojima, and K. Kasai, "Telmisartan inhibits cytokine-induced nuclear factor- $\kappa \mathrm{B}$ activation independently of the peroxisome proliferator-activated receptor $\gamma$," Hypertension Research, vol. 32, no. 9, pp. 765-769, 2009.

[52] G. Umpierrez, S. T. Povedano, F. P. Manghi, L. Shurzinske, and V. Pechtner, "Efficacy and safety of dulaglutide monotherapy versus metformin in type 2 diabetes in a randomized controlled trial (AWARD-3)," Diabetes Care, vol. 37, no. 8, pp. 2168-2176, 2014.

[53] K. Pilipović, Ž. Župan, P. Dolenec, J. Mršić-Pelčić, and G. Župan, "A single dose of PPAR $\gamma$ agonist pioglitazone reduces cortical oxidative damage and microglial reaction following lateral fluid percussion brain injury in rats," Progress in NeuroPsychopharmacology and Biological Psychiatry, vol. 59, pp. 8-20, 2015.

[54] L. Sun, Q. Yuan, T. Xu et al., "Pioglitazone, a peroxisome proliferator-activated receptor $\gamma$ agonist, ameliorates chronic kidney disease by enhancing antioxidative capacity and attenuating angiogenesis in the kidney of a 5/6 nephrectomized rat model," Cellular Physiology and Biochemistry, vol. 38, no. 5, pp. 18311840, 2016.

[55] C. Zou, H. Hu, X. Xi, Z. Shi, G. Wang, and X. Huang, "Pioglitazone protects against renal ischemia-reperfusion injury by enhancing antioxidant capacity," Journal of Surgical Research, vol. 184, no. 2, pp. 1092-1095, 2013.

[56] I. Dovinová, M. Barancik, M. Majzunova et al., "Effects of $\operatorname{PPAR} \gamma$ agonist pioglitazone on redox-sensitive cellular signaling in young spontaneously hypertensive rats," PPAR Research, vol. 2013, Article ID 541871, 11 pages, 2013.

[57] T. Hasegawa, K. Okada, Y. Okita, and D. J. Pinsky, "Antioxidant properties of pioglitazone limit nicotinamide adenine dinucleotide phosphate hydrogen oxidase and augment superoxide dismutase activity in cardiac allotransplantation," Journal of Heart and Lung Transplantation, vol. 30, no. 10, pp. 1186-1196, 2011.

[58] T. Pang, J. Wang, J. Benicky, E. Sánchez-Lemus, and J. M. Saavedra, "Telmisartan directly ameliorates the neuronal inflammatory response to IL- $1 \beta$ partly through the JNK/c-Jun and NADPH oxidase pathways," Journal of Neuroinflammation, vol. 9, article 102, 2012.

[59] B. DeJongh, K. Birkeland, and M. Brenner, "Managing comorbidities in patients with chronic heart failure: first, do no harm," American Journal of Cardiovascular Drugs, vol. 15, no. 3, pp. 171184, 2015.

[60] J. Hippisley-Cox and C. Coupland, "Diabetes treatments and risk of heart failure, cardiovascular disease, and all cause mortality: cohort study in primary care," British Medical Journal, vol. 354, Article ID i3477, 2016.

[61] V. Jearath, R. Vashisht, V. Rustagi, S. Raina, and R. Sharma, "Pioglitazone-induced congestive heart failure and pulmonary edema in a patient with preserved ejection fraction," Journal of Pharmacology and Pharmacotherapeutics, vol. 7, no. 1, p. 41, 2016.

[62] J. J. V. McMurray, H. C. Gerstein, R. R. Holman, and M. A. Pfeffer, "Heart failure: a cardiovascular outcome in diabetes that can no longer be ignored," The Lancet Diabetes and Endocrinology, vol. 2, no. 10, pp. 843-851, 2014.

[63] S. Suh, G. H. Seo, C. H. Jung et al., "Increased risk of hospitalization for heart failure with newly prescribed dipeptidyl peptidase- 4 inhibitors and pioglitazone using the Korean Health Insurance Claims Database," Diabetes and Metabolism Journal, vol. 39, no. 3, pp. 247-252, 2015.

[64] P. Ferdinandy, D. J. Hausenloy, G. Heusch, G. F. Baxter, and R. Schulz, "Interaction of risk factors, comorbidities, and comedications with ischemia/reperfusion injury and cardioprotection by preconditioning, postconditioning, and remote conditioning," Pharmacological Reviews, vol. 66, no. 4, pp. 1142-1174, 2014. 
[65] L. Cui, X. Zhang, R. Yang et al., "Neuroprotection of early and short-time applying atorvastatin in the acute phase of cerebral ischemia: down-regulated 12/15-LOX, p38MAPK and cPLA2 expression, ameliorated BBB permeability," Brain Research, vol. 1325, pp. 164-173, 2010.

[66] E. Barone, G. Cenini, F. Di Domenico et al., "Long-term highdose atorvastatin decreases brain oxidative and nitrosative stress in a preclinical model of Alzheimer disease: a novel mechanism of action," Pharmacological Research, vol. 63, no. 3, pp. 172-180, 2011.

[67] A. C. Melo, S. S. Valença, L. B. Gitirana et al., "Redox markers and inflammation are differentially affected by atorvastatin, pravastatin or simvastatin administered before endotoxininduced acute lung injury," International Immunopharmacology, vol. 17, no. 1, pp. 57-64, 2013.

[68] E. Cadirci, A. Oral, F. Odabasoglu et al., "Atorvastatin reduces tissue damage in rat ovaries subjected to torsion and detorsion: biochemical and histopathologic evaluation," NaunynSchmiedeberg's Archives of Pharmacology, vol. 381, no. 5, pp. 455466, 2010.

[69] K. Axsom, J. S. Berger, and A. Z. Schwartzbard, "Statins and diabetes: the good, the bad, and the unknown," Current atherosclerosis reports, vol. 15, no. 2 , article 299, 2013.

[70] G. Danaei, L. A. García Rodríguez, O. F. Cantero, and M. A. Hernán, "Statins and risk of diabetes: an analysis of electronic medical records to evaluate possible bias due to differential survival," Diabetes Care, vol. 36, no. 5, pp. 1236-1240, 2013.

[71] M. R. Goldstein and L. Mascitelli, "Do statins cause diabetes?" Current Diabetes Reports, vol. 13, no. 3, pp. 381-390, 2013.

[72] M. B. Rocco, "Statins and diabetes risk: fact, fiction, and clinical implications," Cleveland Clinic Journal of Medicine, vol. 79, no. 12, pp. 883-893, 2012.

[73] D. I. Swerdlow and N. Sattar, "A dysglycaemic effect of statins in diabetes: relevance to clinical practice?" Diabetologia, vol. 57, no. 12, pp. 2433-2435, 2014.

[74] Q. Zhou and J. K. Liao, "Pleiotropic effects of statins: basic research and clinical perspectives," Circulation Journal, vol. 74, no. 5, pp. 818-826, 2010.

[75] Y. Kumtepe, F. Odabasoglu, M. Karaca et al., "Protective effects of telmisartan on ischemia/reperfusion injury of rat ovary: biochemical and histopathologic evaluation," Fertility and Sterility, vol. 93, no. 4, pp. 1299-1307, 2010.

[76] I.-N. Bähr, P. Tretter, J. Krüger et al., "High-dose treatment with telmisartan induces monocytic peroxisome proliferatoractivated receptor- $\gamma$ target genes in patients with the metabolic syndrome," Hypertension, vol. 58, no. 4, pp. 725-732, 2011.

[77] H. Fujita, H. Fujishima, T. Morii et al., "Modulation of renal superoxide dismutase by telmisartan therapy in C57BL/6Ins2(Akita) diabetic mice," Hypertension Research, vol. 35, no. 2, pp. 213-220, 2012.

[78] H. He, D. Yang, L. Ma et al., "Telmisartan prevents weight gain and obesity through activation of peroxisome proliferatoractivated receptor- $\delta$-dependent pathways," Hypertension, vol. 55, no. 4, pp. 869-879, 2010.

[79] A. S. Kumar, S. Ghosh, and G. N. Mehta, "Efficient and improved synthesis of Telmisartan," Beilstein Journal of Organic Chemistry, vol. 6, article 25, 2010.

[80] K. Washida, M. Ihara, K. Nishio et al., "Nonhypotensive dose of telmisartan attenuates cognitive impairment partially due to peroxisome proliferator-activated receptor- $\gamma$ activation in mice with chronic cerebral hypoperfusion," Stroke, vol. 41, no. 8, pp. 1798-1806, 2010.
[81] M. Dessì, A. Piras, C. Madeddu et al., "Long-term protective effects of the angiotensin receptor blocker telmisartan on epirubicin-induced inflammation, oxidative stress and myocardial dysfunction," Experimental and Therapeutic Medicine, vol. 2, no. 5, pp. 1003-1009, 2011.

[82] X. Feng, Z. Luo, L. Ma et al., "Angiotensin II receptor blocker telmisartan enhances running endurance of skeletal muscle through activation of the PPAR- $\delta$ /AMPK pathway," Journal of Cellular and Molecular Medicine, vol. 15, no. 7, pp. 1572-1581, 2011.

[83] H. Fujita, T. Sakamoto, K. Komatsu et al., "Reduction of circulating superoxide dismutase activity in type 2 diabetic patients with microalbuminuria and its modulation by telmisartan therapy," Hypertension Research, vol. 34, no. 12, pp. 1302-1308, 2011.

[84] M. Knorr, M. Hausding, S. Kröller-Schuhmacher et al., "Nitroglycerin-induced endothelial dysfunction and tolerance involve adverse phosphorylation and S-glutathionylation of endothelial nitric oxide synthase: beneficial effects of therapy with the AT1 receptor blocker telmisartan," Arteriosclerosis, Thrombosis, and Vascular Biology, vol. 31, no. 10, pp. 2223-2231, 2011.

[85] Y. Maejima, H. Okada, G. Haraguchi et al., “Telmisartan, a unique ARB, improves left ventricular remodeling of infarcted heart by activating PPAR gamma," Laboratory Investigation, vol. 91, no. 6, pp. 932-944, 2011.

[86] C. Yumin, L. Qiong, X. Zibo, L. Wei, C. Li, and X. Zuying, "Telmisartan counteracts TGF- $\beta 1$ induced epithelial-tomesenchymal transition via PPAR- $\gamma$ in human proximal tubule epithelial cells," International Journal of Clinical and Experimental Pathology, vol. 5, no. 6, pp. 522-529, 2012.

[87] H. Kusunoki, Y. Taniyama, J. Azuma et al., “Telmisartan exerts renoprotective actions via peroxisome proliferator-activated receptor- $\gamma /$ hepatocyte growth factor pathway independent of angiotensin II type 1 receptor blockade," Hypertension, vol. 59, no. 2, pp. 308-316, 2012.

[88] T. Pang, J. Benicky, J. Wang, M. Orecna, E. Sanchez-Lemus, and J. M. Saavedra, "Telmisartan ameliorates lipopolysaccharideinduced innate immune response through peroxisome proliferator-activated receptor- $\gamma$ activation in human monocytes," Journal of Hypertension, vol. 30, no. 1, pp. 87-96, 2012.

[89] K. Ozeki, S. Tanida, C. Morimoto et al., "Telmisartan inhibits cell proliferation by blocking nuclear translocation of ProHBEGF C-terminal fragment in colon cancer cells," PLoS ONE, vol. 8, no. 2, Article ID e56770, 2013.

[90] K. Takeuchi, K. Yamamoto, M. Ohishi et al., “Telmisartan modulates mitochondrial function in vascular smooth muscle cells," Hypertension Research, vol. 36, no. 5, pp. 433-439, 2013.

[91] R. L. Engler, G. W. SchmidSchonbein, and R. S. Pavelec, "Leukocyte capillary plugging in myocardial ischemia and reperfusion in the dog," American Journal of Pathology, vol. 111, no. 1, pp. 98-111, 1983.

[92] D. J. Hausenloy and D. M. Yellon, "Myocardial ischemiareperfusion injury: a neglected therapeutic target," The Journal of Clinical Investigation, vol. 123, no. 1, pp. 92-100, 2013.

[93] J. Huffmyer and J. Raphael, "Physiology and pharmacology of myocardial preconditioning and postconditioning," Seminars in Cardiothoracic and Vascular Anesthesia, vol. 13, no. 1, pp. 5-18, 2009.

[94] D. Hilfiker-Kleiner, K. Kaminski, A. Kaminska et al., "Regulation of proangiogenic factor CCN1 in cardiac muscle: impact of ischemia, pressure overload, and neurohumoral activation," Circulation, vol. 109, no. 18, pp. 2227-2233, 2004. 
[95] J. Li, H. Zhang, and C. Zhang, "Role of inflammation in the regulation of coronary blood flow in ischemia and reperfusion: mechanisms and therapeutic implications," Journal of Molecular and Cellular Cardiology, vol. 52, no. 4, pp. 865-872, 2012.

[96] Y. Zhai, H. Petrowsky, J. C. Hong, R. W. Busuttil, and J. W. Kupiec-Weglinski, "Ischaemia-reperfusion injury in liver transplantation-from bench to bedside," Nature Reviews Gastroenterology and Hepatology, vol. 10, no. 2, pp. 79-89, 2013.

[97] Y. Zhai, R. W. Busuttil, and J. W. Kupiec-Weglinski, "Liver ischemia and reperfusion injury: new insights into mechanisms of innate-adaptive immune-mediated tissue inflammation," American Journal of Transplantation, vol. 11, no. 8, pp. 15631569, 2011.

[98] J. G. Godwin, X. Ge, K. Stephan, A. Jurisch, S. G. Tullius, and J. Iacomini, "Identification of a microRNA signature of renal ischemia reperfusion injury," Proceedings of the National Academy of Sciences of the United States of America, vol. 107, no. 32, pp. 14339-14344, 2010.

[99] E. K. van den Akker, O. C. Manintveld, D. A. Hesselink, R. W. F. de Bruin, J. N. M. Ijzermans, and F. J. M. F. Dor, "Protection against renal ischemia-reperfusion injury by ischemic postconditioning," Transplantation, vol. 95, no. 11, pp. 1299-1305, 2013.

[100] A. Kezic, I. Spasojevic, V. Lezaic, and M. Bajcetic, "Mitochondria-targeted antioxidants: future perspectives in kidney ischemia reperfusion injury," Oxidative Medicine and Cellular Longevity, vol. 2016, Article ID 2950503, 12 pages, 2016.

[101] S. Paradis, A. Charles, A. Meyer et al., "Chronology of mitochondrial and cellular events during skeletal muscle ischemiareperfusion," American Journal of Physiology-Cell Physiology, vol. 310, no. 11, pp. C968-C982, 2016.

[102] C. A. da Silva Frias Neto, M. K. Koike, K. R. Saad, P. F. Saad, and E. F. de Souza Montero, "Effects of ischemic preconditioning and cilostazol on muscle ischemia-reperfusion injury in rats," Acta Cirurgica Brasileira, vol. 29, pp. 17-21, 2014.

[103] E. M. Carmo-Araújo, M. Dal-Pai-Silva, V. Dal-Pai, R. Cecchini, and A. L. Anjos Ferreira, "Ischaemia and reperfusion effects on skeletal muscle tissue: morphological and histochemical studies," International Journal of Experimental Pathology, vol. 88, no. 3, pp. 147-154, 2007.

[104] K. Koca, Y. Yurttas, S. Bilgic et al., "Effect of preconditioned hyperbaric oxygen and ozone on ischemia-reperfusion induced tourniquet in skeletal bone of rats," Journal of Surgical Research, vol. 164, no. 1, pp. e83-e89, 2010.

[105] D. B. Rylatt, A. Aitken, T. Bilham, G. D. Condon, N. Embi, and P. Cohen, "Glycogen synthase from rabbit skeletal muscle. Amino acid sequence at the sites phosphorylated by glycogen synthase kinase- 3 , and extension of the $\mathrm{N}$-terminal sequence containing the site phosphorylated by phosphorylase kinase," European Journal of Biochemistry, vol. 107, no. 2, pp. 529-537, 1980.

[106] T. P. Tran, H. Tu, I. I. Pipinos, R. L. Muelleman, H. Albadawi, and Y.-L. Li, "Tourniquet-induced acute ischemia-reperfusion injury in mouse skeletal muscles: involvement of superoxide," European Journal of Pharmacology, vol. 650, no. 1, pp. 328-334, 2011.

[107] A. Y. Andreyev, Y. E. Kushnareva, and A. A. Starkov, "Mitochondrial metabolism of reactive oxygen species," Biochemistry, vol. 70, no. 2, pp. 200-214, 2005.

[108] O. Gateau-Roesch, L. Argaud, and M. Ovize, "Mitochondrial permeability transition pore and postconditioning," Cardiovascular Research, vol. 70, no. 2, pp. 264-273, 2006.
[109] L. Argaud, O. Gateau-Roesch, O. Raisky, J. Loufouat, D. Robert, and M. Ovize, "Postconditioning inhibits mitochondrial permeability transition," Circulation, vol. 111, no. 2, pp. 194-197, 2005.

[110] G. Benard, B. Faustin, E. Passerieux et al., "Physiological diversity of mitochondrial oxidative phosphorylation," American Journal of Physiology -Cell Physiology, vol. 291, no. 6, pp. C1172C1182, 2006.

[111] M. D. Brand and D. G. Nicholls, "Assessing mitochondrial dysfunction in cells," Biochemical Journal, vol. 435, no. 2, pp. 297-312, 2011.

[112] P. Ghafourifar and E. Cadenas, "Mitochondrial nitric oxide synthase," Trends in Pharmacological Sciences, vol. 26, no. 4, pp. 190-195, 2005.

[113] G. Heusch, J. Musiolik, N. Gedik, and A. Skyschally, "Mitochondrial STAT3 activation and cardioprotection by ischemic postconditioning in pigs with regional myocardial ischemia/reperfusion," Circulation Research, vol. 109, no. 11, pp. 1302-1308, 2011.

[114] D. Obal, S. Dettwiler, C. Favoccia, H. Scharbatke, B. Preckel, and W. Schlack, "The influence of mitochondrial KATP-channels in the cardioprotection of preconditioning and postconditioning by sevoflurane in the rat in vivo," Anesthesia and Analgesia, vol. 101, no. 5, pp. 1252-1260, 2005.

[115] J. M. Suski, M. Lebiedzinska, M. Bonora, P. Pinton, J. Duszynski, and M. R. Wieckowski, "Relation between mitochondrial membrane potential and ROS formation," Methods in Molecular Biology, vol. 810, pp. 183-205, 2012.

[116] A. G. Estévez and J. Jordán, "Nitric oxide and superoxide, a deadly cocktail," Annals of the New York Academy of Sciences, vol. 962, pp. 207-211, 2002.

[117] M. W. Broadhead, R. K. Kharbanda, M. J. Peters, and R. J. MacAllister, "KATP channel activation induces ischemic preconditioning of the endothelium in humans in vivo," Circulation, vol. 110, no. 15, pp. 2077-2082, 2004.

[118] S. P. Loukogeorgakis, R. Williams, A. T. Panagiotidou et al., "Transient limb ischemia induces remote preconditioning and remote postconditioning in humans by a $\mathrm{K}_{A T P}$ channeldependent mechanism," Circulation, vol. 116, no. 12, pp. 13861395, 2007.

[119] E. Birben, U. M. Sahiner, C. Sackesen, S. Erzurum, and O. Kalayci, "Oxidative stress and antioxidant defense," World Allergy Organization Journal, vol. 5, no. 1, pp. 9-19, 2012.

[120] A. Daiber, M. Mader, P. Stamm et al., "Oxidative stress and vascular function," Cell Membranes and Free Radical Research, vol. 5, no. 1, pp. 221-232, 2013.

[121] K. Jomova, D. Vondrakova, M. Lawson, and M. Valko, "Metals, oxidative stress and neurodegenerative disorders," Molecular and Cellular Biochemistry, vol. 345, no. 1-2, pp. 91-104, 2010.

[122] D. P. Jones, "Redefining oxidative stress," Antioxidants \& Redox Signaling, vol. 8, no. 9-10, pp. 1865-1879, 2006.

[123] M. P. Lesser, "Oxidative stress in marine environments: biochemistry and physiological ecology," Annual Review of Physiology, vol. 68, pp. 253-278, 2006.

[124] J. Li, O. Wuliji, W. Li, Z.-G. Jiang, and H. A. Ghanbari, "Oxidative stress and neurodegenerative disorders," International Journal of Molecular Sciences, vol. 14, no. 12, pp. 2443824475, 2013.

[125] G.-Y. Liou and P. Storz, "Reactive oxygen species in cancer," Free Radical Research, vol. 44, no. 5, pp. 479-496, 2010. 
[126] M. J. Morgan and Z.-G. Liu, "Crosstalk of reactive oxygen species and NF- $\kappa \mathrm{B}$ signaling," Cell Research, vol. 21, no. 1, pp. 103-115, 2011.

[127] S. M. Davidson and M. R. Duchen, "Endothelial mitochondria: contributing to vascular function and disease," Circulation Research, vol. 100, no. 8, pp. 1128-1141, 2007.

[128] J. P. Kehrer, "The Haber-Weiss reaction and mechanisms of toxicity," Toxicology, vol. 149, no. 1, pp. 43-50, 2000.

[129] Y. Takada, A. Mukhopadhyay, G. C. Kundu, G. H. Mahabeleshwar, S. Singh, and B. B. Aggarwal, "Hydrogen peroxide activates NF- $\kappa \mathrm{B}$ through tyrosine phosphorylation of $\mathrm{I} \kappa \mathrm{B} \alpha$ and serine phosphorylation of p65. Evidence for the involvement of $\mathrm{I} \kappa \mathrm{B} \alpha$ kinase and Syk protein-tyrosine kinase," The Journal of Biological Chemistry, vol. 278, no. 26, pp. 24233-24241, 2003.

[130] B. Kalyanaraman, "Teaching the basics of redox biology to medical and graduate students: oxidants, antioxidants and disease mechanisms," Redox Biology, vol. 1, no. 1, pp. 244-257, 2013.

[131] J. Camps, A. García-Heredia, A. Rull et al., "PPARs in regulation of paraoxonases: control of oxidative stress and inflammation pathways," PPAR Research, vol. 2012, Article ID 616371, 10 pages, 2012.

[132] J. Ninomiya-Tsuji, K. Kishimoto, A. Hiyama, J.-I. Inoue, Z. Cao, and K. Matsumoto, "The kinase TAK1 can activate the NIK$\mathrm{I} \kappa \mathrm{B}$ as well as the MAP kinase cascade in the IL-1 signalling pathway," Nature, vol. 398, no. 6724, pp. 252-256, 1999.

[133] K. Schulze-Osthoff, D. Ferrari, K. Riehemann, and S. Wesselborg, "Regulation of NF- $\kappa \mathrm{B}$ activation by MAP kinase cascades," Immunobiology, vol. 198, no. 1-3, pp. 35-49, 1997.

[134] N. L. Malinin, M. P. Boldin, A. V. Kovalenko, and D. Wallach, "MAP3K-related kinase involved in NF- $\kappa$ B induction by TNF, CD95 and IL-1," Nature, vol. 385, no. 6616, pp. 540-544, 1997.

[135] P. Tieri, A. Termanini, E. Bellavista, S. Salvioli, M. Capri, and C. Franceschi, "Charting the NF- $\kappa$ B pathway interactome map," PLoS ONE, vol. 7, no. 3, Article ID e32678, 2012.

[136] T. Bouwmeester, A. Bauch, H. Ruffner et al., "A physical and functional map of the human TNF- $\alpha / \mathrm{NF}-\kappa \mathrm{B}$ signal transduction pathway," Nature Cell Biology, vol. 6, no. 2, pp. 97-105, 2004.

[137] E. De Smaele, F. Zazzeroni, S. Papa et al., "Induction of gadd $4 \beta$ by NF- $\kappa$ B downregulates pro-apoptotic JNK signalling," Nature, vol. 414, no. 6861, pp. 308-313, 2001.

[138] S. Papa, F. Zazzeroni, C. Bubici et al., "Gadd $45 \beta$ mediates the NF- $\kappa \mathrm{B}$ suppression of JNK signalling by targeting MKK7/JNKK2," Nature Cell Biology, vol. 6, no. 2, pp. 146-153, 2004.

[139] N. D. Perkins, "Integrating cell-signalling pathways with NF- $\kappa \mathrm{B}$ and IKK function," Nature Reviews Molecular Cell Biology, vol. 8, no. 1, pp. 49-62, 2007.

[140] M. Zhu, J. Feng, E. Lucchinetti et al., "Ischemic postconditioning protects remodeled myocardium via the PI3K-PKB/Akt reperfusion injury salvage kinase pathway," Cardiovascular Research, vol. 72, no. 1, pp. 152-162, 2006.

[141] M. Guha and N. Mackman, "The phosphatidylinositol 3-kinaseAkt pathway limits lipopolysaccharide activation of signaling pathways and expression of inflammatory mediators in human monocytic cells," Journal of Biological Chemistry, vol. 277, no. 35, pp. 32124-32132, 2002.

[142] D. J. Hausenloy and D. M. Yellon, "Survival kinases in ischemic preconditioning and postconditioning," Cardiovascular Research, vol. 70, no. 2, pp. 240-253, 2006.

[143] A. A. Habib, S. Chatterjee, S.-K. Park, R. R. Ratan, S. Lefebvre, and T. Vartanian, "The epidermal growth factor receptor engages receptor interacting protein and nuclear factor- $\kappa \mathrm{B}$ (NF$\kappa \mathrm{B})$-inducing kinase to activate NF- $\kappa \mathrm{B}$ : identification of a novel receptor-tyrosine kinase signalosome," The Journal of Biological Chemistry, vol. 276, no. 12, pp. 8865-8874, 2001.

[144] Y. C. Park, C. H. Lee, H. S. Kang, H. T. Chung, and H. D. Kim, "Wortmannin, a specific inhibitor of phosphatidylinositol-3kinase, enhances LPS-induced NO production from murine peritoneal macrophages," Biochemical and Biophysical Research Communications, vol. 240, no. 3, pp. 692-696, 1997.

[145] D. Wang, S. D. Westerheide, J. L. Hanson, and A. S. Baldwin Jr., "Tumor necrosis factor $\alpha$-induced phosphorylation of RelA/p65 on $\operatorname{Ser}^{529}$ is controlled by casein kinase II," The Journal of Biological Chemistry, vol. 275, no. 42, pp. 32592-32597, 2000.

[146] Q. Zhao and F. S. Lee, "Mitogen-activated protein kinase/ERK kinase kinases 2 and 3 activate nuclear factor- $\kappa \mathrm{B}$ through $\mathrm{I} \kappa \mathrm{B}$ kinase- $\alpha$ and I $\kappa$ B kinase- $\beta$," Journal of Biological Chemistry, vol. 274, no. 13, pp. 8355-8358, 1999.

[147] M. Delhase, S.-Y. Kim, H. Lee et al., "Correction for Delhase et al., TANK-binding kinase 1 (TBK1) controls cell survival through PAI-2/serpinB2 and transglutaminase 2," Proceedings of the National Academy of Sciences of the United States of America, vol. 109, no. 11, pp. 4332-4335, 2012.

[148] C. Alberti, P. Pinciroli, B. Valeri et al., "Ligand-dependent EGFR activation induces the co-expression of IL- 6 and PAI-1 via the NFkB pathway in advanced-stage epithelial ovarian cancer," Oncogene, vol. 31, no. 37, pp. 4139-4149, 2012.

[149] D. P. Bartel, "MicroRNAs: genomics, biogenesis, mechanism, and function," Cell, vol. 116, no. 2, pp. 281-297, 2004.

[150] D. P. Bartel, "MicroRNAs: target Recognition and Regulatory Functions," Cell, vol. 136, no. 2, pp. 215-233, 2009.

[151] J. Bauersachs and T. Thum, "Biogenesis and regulation of cardiovascular MicroRNAs," Circulation Research, vol. 109, no. 3, pp. 334-347, 2011.

[152] A. K. Frank, J. I.-J. Leu, Y. Zhou et al., "The codon 72 polymorphism of p53 regulates interaction with NF- $\kappa \mathrm{B}$ and transactivation of genes involved in immunity and inflammation," Molecular and Cellular Biology, vol. 31, no. 6, pp. 1201-1213, 2011.

[153] D. Iliopoulos, H. A. Hirsch, and K. Struhl, "An epigenetic switch involving NF- $\kappa$ B, Lin28, Let-7 MicroRNA, and IL6 links inflammation to cell transformation," Cell, vol. 139, no. 4, pp. 693-706, 2009.

[154] A. Oeckinghaus and S. Ghosh, "The NF-kappaB family of transcription factors and its regulation," Cold Spring Harbor Perspectives in Biology, vol. 1, no. 4, Article ID a000034, 2009.

[155] H. Sabatel, E. Di Valentin, G. Gloire, F. Dequiedt, J. Piette, and Y. Habraken, "Phosphorylation of p65(ReLA) on ser 547 by ATM represses NF- $\kappa$ b-dependent transcription of specific genes after genotoxic stress," PLoS ONE, vol. 7, no. 6, Article ID e38246, 2012.

[156] T.-X. Xie, Z. Xia, N. Zhang, W. Gong, and S. Huang, "Constitutive NF- $\kappa \mathrm{B}$ activity regulates the expression of VEGF and IL8 and tumor angiogenesis of human glioblastoma," Oncology Reports, vol. 23, no. 3, pp. 725-732, 2010.

[157] Z. Pan, X. Sun, J. Ren et al., "miR-1 Exacerbates Cardiac Ischemia-Reperfusion Injury in Mouse Models," PLoS ONE, vol. 7, no. 11, Article ID e50515, 2012.

[158] R. W. Carthew and E. J. Sontheimer, "Origins and mechanisms of miRNAs and siRNAs," Cell, vol. 136, no. 4, pp. 642-655, 2009.

[159] T. Li, M. J. Morgan, S. Choksi, Y. Zhang, Y.-S. Kim, and Z.G. Liu, "MicroRNAs modulate the noncanonical transcription 
factor NF- $\kappa \mathrm{B}$ pathway by regulating expression of the kinase IKK $\alpha$ during macrophage differentiation," Nature Immunology, vol. 11, no. 9, pp. 799-805, 2010.

[160] X. Ma, L. E. Becker Buscaglia, J. R. Barker, and Y. Li, "MicroRNAs in NF- $\kappa$ B signaling," Journal of Molecular Cell Biology, vol. 3, no. 3, pp. 159-166, 2011.

[161] J. Niu, Y. Shi, G. Tan et al., "DNA damage induces NF- $\kappa$ Bdependent microRNA-21 up-regulation and promotes breast cancer cell invasion," The Journal of Biological Chemistry, vol. 287, no. 26, pp. 21783-21795, 2012.

[162] B. Schroen and S. Heymans, "Small but smart-microRNAs in the centre of inflammatory processes during cardiovascular diseases, the metabolic syndrome, and ageing," Cardiovascular Research, vol. 93, no. 4, pp. 605-613, 2012.

[163] Y. Ye, J. R. Perez-Polo, J. Qian, and Y. Birnbaum, "The role of microRNA in modulating myocardial ischemia-reperfusion injury," Physiological Genomics, vol. 43, no. 10, pp. 534-542, 2011.

[164] S. Zhang, C. Shan, G. Kong, Y. Du, L. Ye, and X. Zhang, "MicroRNA-520e suppresses growth of hepatoma cells by targeting the NF- $\kappa \mathrm{B}$-inducing kinase (NIK)," Oncogene, vol. 31, no. 31, pp. 3607-3620, 2012.

[165] J. Qin, J. Yao, G. Cui et al., "TLR8-mediated NF- $\kappa$ B and JNK activation are TAK1-independent and MEKK3-dependent," Journal of Biological Chemistry, vol. 281, no. 30, pp. 21013-21021, 2006.

[166] L. Arbibe, J.-P. Mira, N. Teusch et al., “Toll-like receptor 2mediated NF- $\kappa \mathrm{B}$ activation requires a Racl-dependent pathway," Nature Immunology, vol. 1, no. 6, pp. 533-540, 2000.

[167] T. Ha, L. Liu, J. Kelley, R. Kao, D. Williams, and C. Li, “Tolllike receptors: new players in myocardial ischemia/reperfusion injury," Antioxidants and Redox Signaling, vol. 15, no. 7, pp. 18751893, 2011.

[168] Q. Huang, J. Yang, Y. Lin et al., "Differential regulation of interleukin 1 receptor and toll-like receptor signaling by MEKK3," Nature Immunology, vol. 5, no. 1, pp. 98-103, 2003.

[169] J. Wang, Y. Cai, L.-J. Shao et al., "Ctivation of NF- $\kappa$ B by TMPRSS2/ERG fusion isoforms through toll-like receptor-4," Cancer Research, vol. 71, no. 4, 2011.

[170] J.-X. Wang, J.-Q. Jiao, Q. Li et al., "miR-499 regulates mitochondrial dynamics by targeting calcineurin and dynamin-related protein-1," Nature Medicine, vol. 17, no. 1, pp. 71-78, 2011.

[171] A. V. Ougolkov, N. D. Bone, M. E. Fernandez-Zapico, N. E. Kay, and D. D. Billadeau, "Inhibition of glycogen synthase kinase3 activity leads to epigenetic silencing of nuclear factor $\kappa \mathrm{B}$ target genes and induction of apoptosis in chronic lymphocytic leukemia B cells," Blood, vol. 110, no. 2, pp. 735-742, 2007.

[172] A. V. Ougolkov, M. E. Fernandez-Zapico, D. N. Savoy, R. A. Urrutia, and D. D. Billadeau, "Glycogen synthase kinase- $3 \beta$ participates in nuclear factor $\kappa \mathrm{B}$-mediated gene transcription and cell survival in pancreatic cancer cells," Cancer Research, vol. 65, no. 6, pp. 2076-2081, 2005.

[173] A. Shakoori, A. Ougolkov, Z. W. Yua et al., "Deregulated GSK3 $\beta$ activity in colorectal cancer: its association with tumor cell survival and proliferation," Biochemical and Biophysical Research Communications, vol. 334, no. 4, pp. 1365-1373, 2005.

[174] J. S. Bae, M. K. Jang, S. Hong et al., "Phosphorylation of NF$\kappa \mathrm{B}$ by calmodulin-dependent kinase IV activates anti-apoptotic gene expression," Biochemical and Biophysical Research Communications, vol. 305, no. 4, pp. 1094-1098, 2003.

[175] R. F. Schwabe and D. A. Brenner, "Role of glycogen synthase kinase- 3 in TNF- $\alpha$-induced NF- $\kappa$ B activation and apoptosis in hepatocytes," American Journal of Physiology-Gastrointestinal and Liver Physiology, vol. 283, no. 1, pp. G204-G211, 2002.

[176] S. Sciarretta, N. Hariharan, Y. Monden, D. Zablocki, and J. Sadoshima, "Is autophagy in response to ischemia and reperfusion protective or detrimental for the heart?" Pediatric Cardiology, vol. 32, no. 3, pp. 275-281, 2011.

[177] J. Caamaño and C. A. Hunter, "NF- $\kappa$ B family of transcription factors: central regulators of innate and adaptive immune functions," Clinical Microbiology Reviews, vol. 15, no. 3, pp. 414429, 2002.

[178] A. Katsman, K. Umezawa, and B. Bonavida, "Chemosensitization and immunosensitization of resistant cancer cells to apoptosis and inhibition of metastasis by the specific NF- $\kappa \mathrm{B}$ inhibitor DHMEQ," Current Pharmaceutical Design, vol. 15, no. 7, pp. 792-808, 2009.

[179] K. D. Taganov, M. P. Boldin, K.-J. Chang, and D. Baltimore, "NF$\kappa \mathrm{B}$-dependent induction of microRNA miR-146, an inhibitor targeted to signaling proteins of innate immune responses," Proceedings of the National Academy of Sciences of the United States of America, vol. 103, no. 33, pp. 12481-12486, 2006.

[180] L. Tornatore, A. K. Thotakura, J. Bennett, M. Moretti, and G. Franzoso, "The nuclear factor kappa B signaling pathway: integrating metabolism with inflammation," Trends in Cell Biology, vol. 22, no. 11, pp. 557-566, 2012.

[181] N. H. Dryden, A. Sperone, S. Martin-Almedina et al., "The transcription factor Erg controls endothelial cell quiescence by repressing activity of nuclear factor (NF)- $\kappa$ B p65," Journal of Biological Chemistry, vol. 287, no. 15, pp. 12331-12342, 2012.

[182] L. Li and M. D. Okusa, "Macrophages, dendritic cells, and kidney ischemia-reperfusion injury," Seminars in Nephrology, vol. 30, no. 3, pp. 268-277, 2010.

[183] C. Duehrkop, Y. Banz, R. Spirig et al., "C1 esterase inhibitor reduces lower extremity ischemia/reperfusion injury and associated lung damage," PLoS ONE, vol. 8, no. 8, Article ID e72059, 2013.

[184] M. R. G. A. Santos, A. C. Celotto, V. K. Capellini, P. R. B. Evora, C. E. Piccinato, and E. E. Joviliano, "The protective effect of cilostazol on isolated rabbit femoral arteries under conditions of ischemia and reperfusion: the role of the nitric oxide pathway," Clinics, vol. 67, no. 2, pp. 171-178, 2012.

[185] Q. C. Yong, S. W. Lee, C. S. Foo, K. L. Neo, X. Chen, and J.S. Bian, "Endogenous hydrogen sulphide mediates the cardioprotection induced by ischemic postconditioning," American Journal of Physiology-Heart and Circulatory Physiology, vol. 295, no. 3, pp. H1330-H1340, 2008.

[186] S. A. Gabel, V. R. Walker, R. E. London, C. Steenbergen, K. S. Korach, and E. Murphy, "Estrogen receptor beta mediates gender differences in ischemia/reperfusion injury," Journal of Molecular and Cellular Cardiology, vol. 38, no. 2, pp. 289-297, 2005.

[187] E. Murphy and C. Steenbergen, "Gender-based differences in mechanisms of protection in myocardial ischemia-reperfusion injury," Cardiovascular Research, vol. 75, no. 3, pp. 478-486, 2007.

[188] S. Renolleau, S. Fau, and C. Charriaut-Marlangue, "Genderrelated differences in apoptotic pathways after neonatal cerebral ischemia," The Neuroscientist, vol. 14, no. 1, pp. 46-52, 2008.

[189] D. A. Brown, J. M. Lynch, C. J. Armstrong et al., "Susceptibility of the heart to ischaemia-reperfusion injury and exerciseinduced cardioprotection are sex-dependent in the rat," Journal of Physiology, vol. 564, no. 2, pp. 619-630, 2005. 
[190] P. S. Herson, J. Palmateer, and P. D. Hurn, "Biological sex and mechanisms of ischemic brain injury," Translational Stroke Research, vol. 4, no. 4, pp. 413-419, 2013.

[191] A. Kher, K. K. Meldrum, M. Wang, B. M. Tsai, J. M. Pitcher, and D. R. Meldrum, "Cellular and molecular mechanisms of sex differences in renal ischemia-reperfusion injury," Cardiovascular Research, vol. 67, no. 4, pp. 594-603, 2005.

[192] S. Cianchetti, A. Del Fiorentino, R. Colognato, R. Di Stefano, F. Franzoni, and R. Pedrinelli, "Anti-inflammatory and antioxidant properties of telmisartan in cultured human umbilical vein endothelial cells," Atherosclerosis, vol. 198, no. 1, pp. 22-28, 2008.

[193] K. Hao, Y.-C. Chen, Y.-G. Cao, D. Yu, X.-Q. Liu, and G.J. Wang, "Pharmacokinetic-pharmacodynamic modeling of telmisartan using an indirect response model in spontaneously hypertensive rats," Acta Pharmacologica Sinica, vol. 28, no. 5, pp. 738-743, 2007.

[194] I. Imayama, T. Ichiki, K. Inanaga et al., "Telmisartan downregulates angiotensin II type 1 receptor through activation of peroxisome proliferator-activated receptor $\gamma$," Cardiovascular Research, vol. 72, no. 1, pp. 184-190, 2006.

[195] W. Z. Wang, "Investigation of reperfusion injury and ischemic preconditioning in microsurgery," Microsurgery, vol. 29, no. 1, pp. 72-79, 2009.

[196] C. Dezfulian, M. Garrett, and N. R. Gonzalez, "Clinical application of preconditioning and postconditioning to achieve neuroprotection," Translational Stroke Research, vol. 4, no. 1, pp. 19-24, 2013.

[197] P. Ferdinandy, R. Schulz, and G. F. Baxter, "Interaction of cardiovascular risk factors with myocardial ischemia/reperfusion injury, preconditioning, and postconditioning," Pharmacological Reviews, vol. 59, no. 4, pp. 418-458, 2007.

[198] N. Gassanov, A. M. Nia, E. Caglayan, and F. Er, "Remote ischemic preconditioning and renoprotection: from myth to a novel therapeutic option?" Journal of the American Society of Nephrology, vol. 25, no. 2, pp. 216-224, 2014.

[199] A. Granfeldt, D. J. Lefer, and J. Vinten-Johansen, "Protective ischaemia in patients: preconditioning and postconditioning," Cardiovascular Research, vol. 83, no. 2, pp. 234-246, 2009.

[200] D. J. Hausenloy and D. M. Yellon, "Remote ischaemic preconditioning: underlying mechanisms and clinical application," Cardiovascular Research, vol. 79, no. 3, pp. 377-386, 2008.

[201] R. K. Kharbanda, T. T. Nielsen, and A. N. Redington, "Translation of remote ischaemic preconditioning into clinical practice," The Lancet, vol. 374, no. 9700, pp. 1557-1565, 2009.

[202] S. P. Loukogeorgakis, A. T. Panagiotidou, D. M. Yellon, J. E. Deanfield, and R. J. MacAllister, "Postconditioning protects against endothelial ischemia-reperfusion injury in the human forearm," Circulation, vol. 113, no. 7, pp. 1015-1019, 2006.

[203] J.-Y. Hahn, Y. B. Song, E. K. Kim et al., "Ischemic postconditioning during primary percutaneous coronary intervention: the POST Randomized Trial," Circulation, vol. 134, no. 21, 2013.

[204] D. Brevoord, P. Kranke, M. Kuijpers, N. Weber, M. Hollmann, and B. Preckel, "Remote ischemic conditioning to protect against ischemia-reperfusion injury: a systematic review and meta-analysis," PLoS ONE, vol. 7, no. 7, Article ID e42179, 2012. 


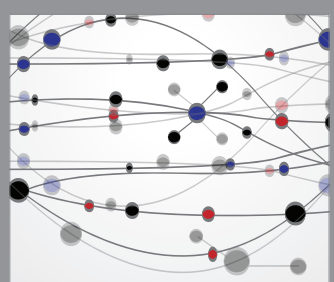

The Scientific World Journal
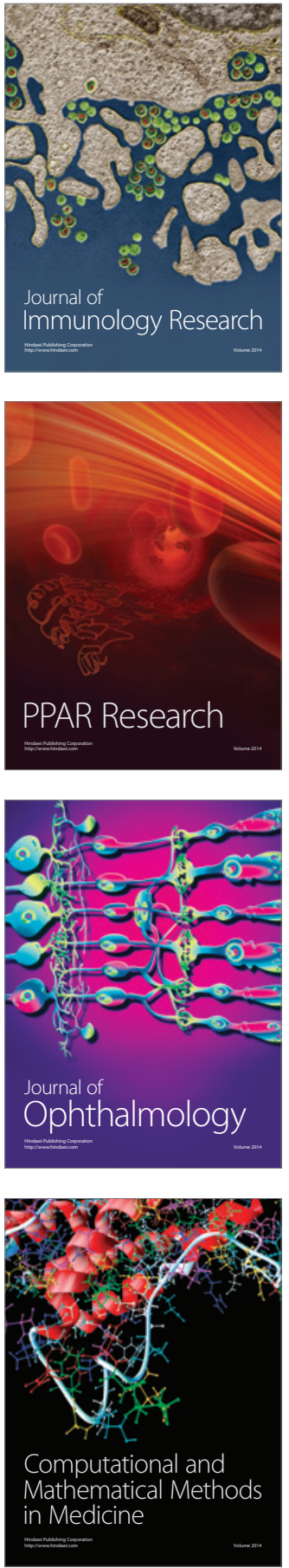

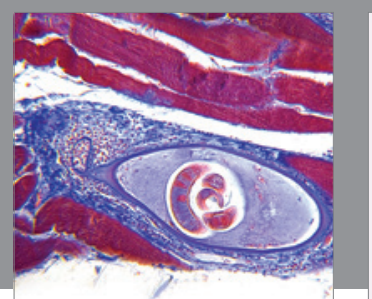

Gastroenterology Research and Practice

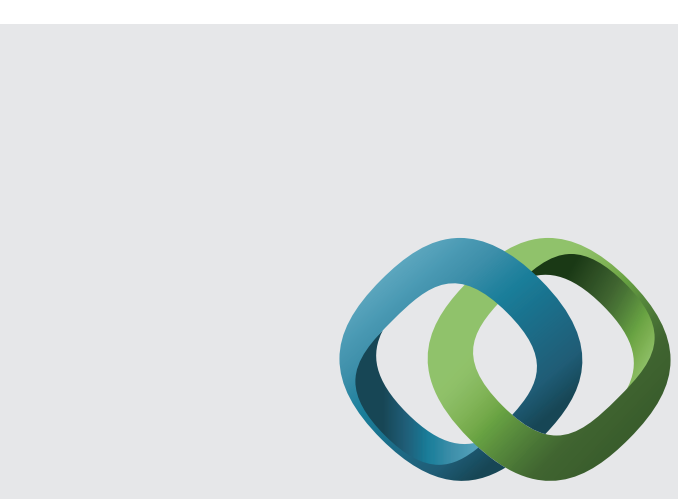

\section{Hindawi}

Submit your manuscripts at

http://www.hindawi.com
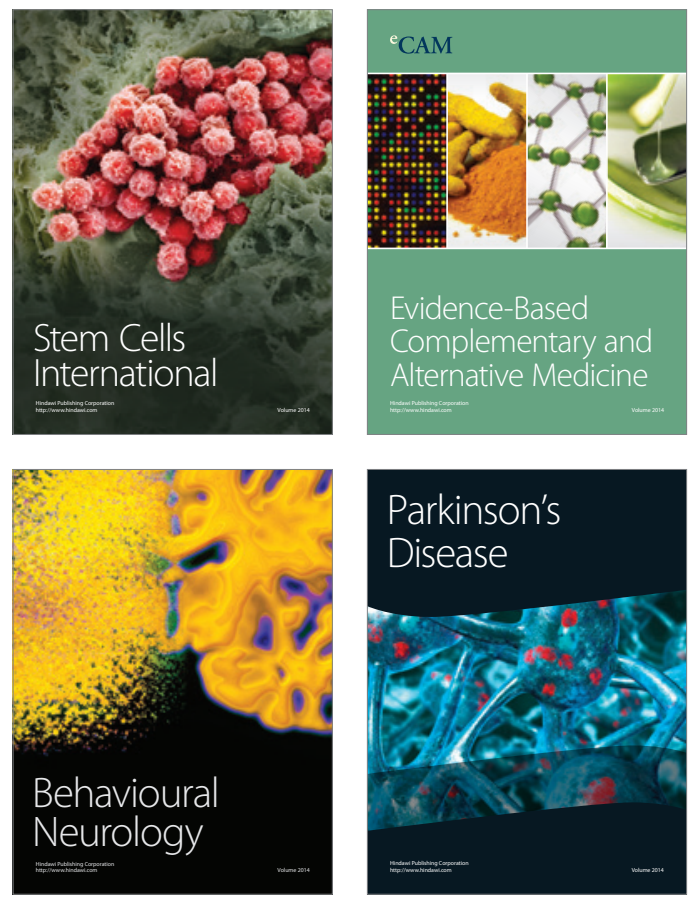
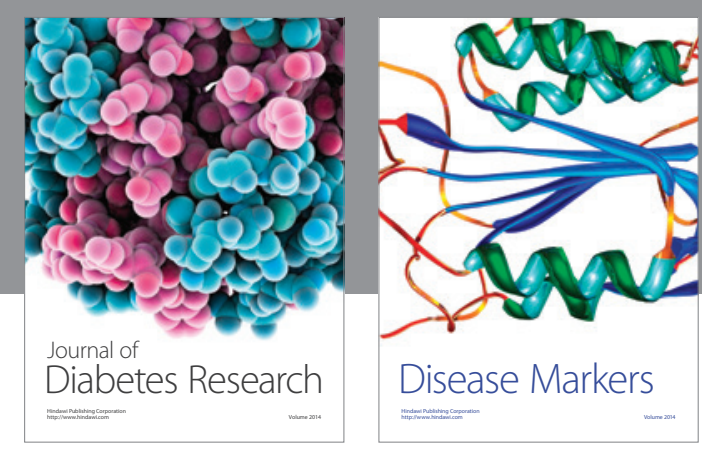

Disease Markers
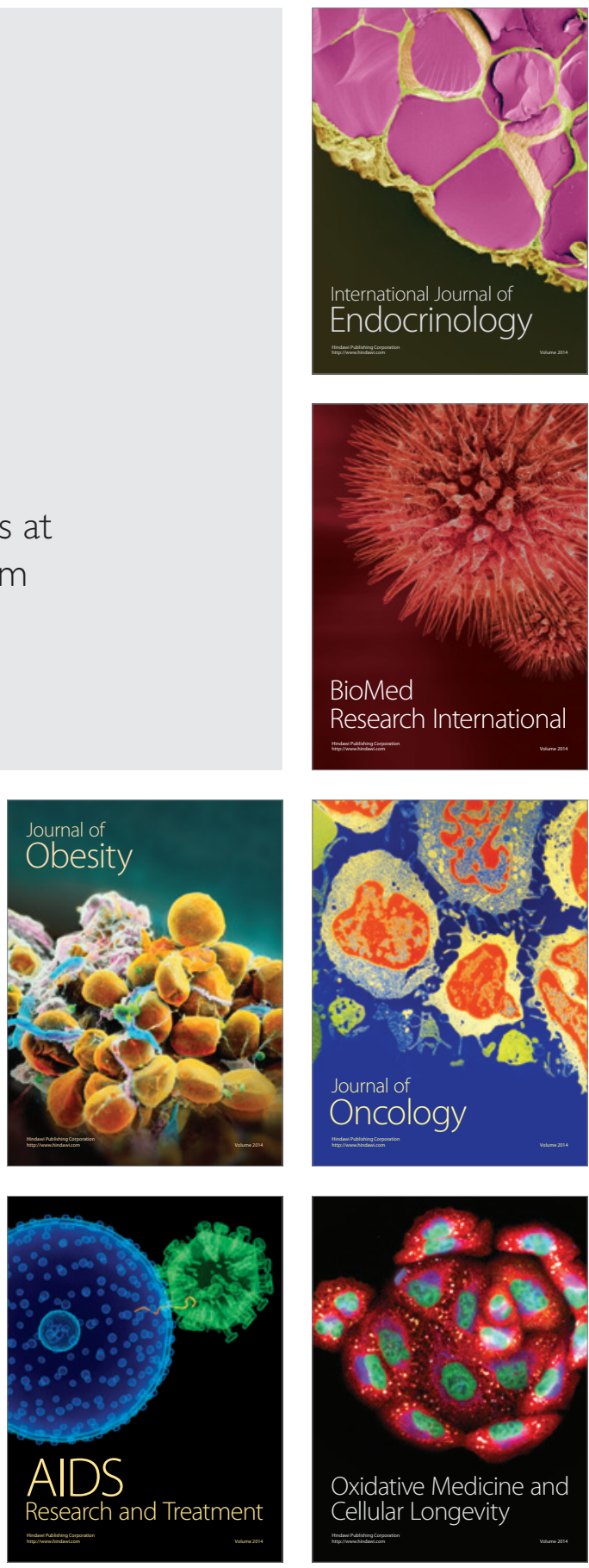